\title{
Current Status and Potential Therapeutic Strategies for Using Non-coding RNA to Treat Diabetic Cardiomyopathy
}

\author{
Amit K. Rai' ${ }^{1}$, Brooke Lee ${ }^{1}$, Ramesh Gomez ${ }^{2}$, Deepu Rajendran ${ }^{3}$, Mahmood Khan ${ }^{1,4}$ and \\ Venkata Naga Srikanth Garikipati ${ }^{*}$ \\ ${ }^{1}$ Department of Emergency Medicine, Institute of Behavioral Medicine and Research, Dorothy M. Davis Heart Lung \\ and Research Institute, The Ohio State University Wexner Medical Center, Columbus, OH, United States, ${ }^{2}$ Department \\ of Endocrinology, Government Medical College, Thiruvananthapuram, India, ${ }^{3}$ Department of Cardiology, Travancore Medical \\ College, Kollam, India, ${ }^{4}$ Department of Physiology and Cell Biology, The Ohio State University Wexner Medical Center, \\ Columbus, $\mathrm{OH}$, United States
}

OPEN ACCESS

Edited by:

James Todd Pearson, National Cerebral and Cardiovascular

Center, Japan

Reviewed by:

Paras Kumar Mishra,

University of Nebraska Medical

Center, United States

Rajarajan Amirthalingam

Thandavarayan,

Houston Methodist Hospital,

United States

*Correspondence:

Venkata Naga Srikanth Garikipati venkata.garikipati@osumc.edu

Specialty section: This article was submitted to Integrative Physiology, a section of the journal

Frontiers in Physiology

Received: 30 September 2020 Accepted: 09 December 2020

Published: 22 January 2021

Citation:

Rai AK, Lee B, Gomez R,

Rajendran D, Khan M and Garikipati VNS (2021) Current Status and Potential Therapeutic Strategies for Using Non-coding RNA to Treat

Diabetic Cardiomyopathy.

Front. Physiol. 11:612722. doi: 10.3389/fphys.2020.612722
Diabetic cardiomyopathy (DMCM) is the leading cause of mortality and morbidity among diabetic patients. DMCM is characterized by an increase in oxidative stress with systemic inflammation that leads to cardiac fibrosis, ultimately causing diastolic and systolic dysfunction. Even though DMCM pathophysiology is well studied, the approach to limit this condition is not met with success. This highlights the need for more knowledge of underlying mechanisms and innovative therapies. In this regard, emerging evidence suggests a potential role of non-coding RNAs (ncRNAs), including micro-RNAs (miRNAs), long non-coding RNAs (IncRNAs), and circular RNAs (circRNAs) as novel diagnostics, mechanisms, and therapeutics in the context of DMCM. However, our understanding of ncRNAs' role in diabetic heart disease is still in its infancy. This review provides a comprehensive update on pre-clinical and clinical studies that might develop therapeutic strategies to limit/prevent DMCM.

Keywords: diabetic cardiomyopathy, long non-coding RNA, microRNA, circular RNA, diastolic dysfunction

\section{IMPACT OF DIABETES AND OBESITY ON THE BODY AND THE GLOBE CURRENTLY}

Obesity is presently a pandemic problem affecting both developed and developing countries ( $\mathrm{Ng}$ et al., 2014). The projected prevalence of obesity in adults in the United States is estimated to be $49.8 \%$, indicating that one in two individuals will have obesity (Ward et al., 2019). The United States's most common body mass index (BMI) category will be severe obesity by 2030. In children and adolescents, obesity has risen 10-fold over the past 40 years, taking 124 million from 11 million (World Health Organization, 2018). Though the rise in children's BMI has plateaued over decades, the trend is still alarming in South Asia, the Middle East, and North Africa, where the prevalence is more than 20\% (Abarca-Gómez et al., 2017). In children with class 3 obesity, less than $26 \mathrm{~h}$ of intensive behavioral therapy mechanisms, lasting between 6 and 12 months, was shown to be associated with higher systolic and diastolic blood pressures, higher odds for hypertension, type 2 diabetes mellitus (T2DM), and obstructive sleep apnea (Tsao-Wu et al., 2019). The overweight 
trend in adolescence is associated with higher cardiovascular (CV) and all-cause mortality in men after a 55-year follow-up (Must et al., 1992).

Large community-based follow-up studies have shown that a higher BMI is associated with heart failure (HF), more for women (7\%) compared with men (5\%) (Kenchaiah et al., 2002). The duration of obesity is important and for every two additional years living with obesity, the hazard ratio for all-cause and $\mathrm{CV}$ mortality was 1.06 and 1.07, respectively (Kenchaiah et al., 2002). The relative risk of $\mathrm{CV}$ death among the heaviest individuals was 1.57 in comparison with the category with the lowest BMI in meta-analytic studies (Jiang et al., 2013). Within different classes of obesity, independent of gender, smoking status, and educational level, CV mortality was 1.29 among class $1,1.87$ among class 2, and 2.2 among class 3 of obesity (Jiang et al., 2013). Obesity and hyperglycemia in C57BL/6J $d b / d b$ mice were found to be associated with hypertrophy of the cardiac myocyte, thickening of the perimysial collagen, vascular rarefaction, and mild fibrosis of the endomysium and perivascular region, mainly by the addition of the extracellular matrix via fibroblasts in the interstitium (Alex et al., 2018).

A meta-analysis showed that an obesity paradox exists in HF, and the nadir was seen in overweight subjects (Mahajan et al., 2020). The obese and overweight subjects, classified based on their pre-HF BMI, had lower mortality rates when admitted for HF (Pokharel et al., 2017). Mahajan et al. (2020) also showed that intentional weight loss in obese subjects without established HF was associated with significant improvement in left ventricular (LV) diastolic dysfunction and reduced LV size. Though there is a decline in the incidence of T2DM in the United States, which is primarily attributed to the decline in Hispanic whites, the global prevalence of diabetes among adults over 18 years of age rose from $4.7 \%$ in 1980 to $8.5 \%$ in 2014 , with a $5 \%$ increase in premature mortality due to diabetes between 2000 and 2016 (Centers for Disease Control and Prevention, 2020). South Asians have a high-fat percentage for any given BMI, making them vulnerable to metabolic diseases (Lear et al., 2007). About 19 million adults ages 20-79 were living with diabetes in the International Diabetes Federation of Africa Region in 2019, and the number is estimated to increase to 47 million by 2045 . Another 45 million adults (20-79) in this region have impaired glucose tolerance (IGT), and the figure is expected to reach 110 million by 2045 (Cho et al., 2018).

Diabetic cardiomyopathy (DMCM) denotes LV dysfunction in diabetic subjects (Figure 1) with or without preserved ejection fraction $(\mathrm{pEF})$ due to interstitial fibrosis and repercussions of LV hypertrophy caused by a myriad of factors (LorenzoAlmoros et al., 2017). Leyden was the first to postulate that diabetes can cause HF in his journal, Asthma, and Diabetes Mellitus, in as early as 1881 (Leyden, 1881). Shirley Rubler and team first used the term DMCM and HF in the absence of significant coronary artery disease in four patients with T2DM and glomerulosclerosis. There is a two- to four-fold increase in $\mathrm{HF}$ incidence rates in diabetic individuals compared with nondiabetic individuals (Dunlay et al., 2019). The histopathology revealed diffuse fibrotic strands extending between myocardial muscle bundles and myofibrillar hypertrophy (Rubler et al.,

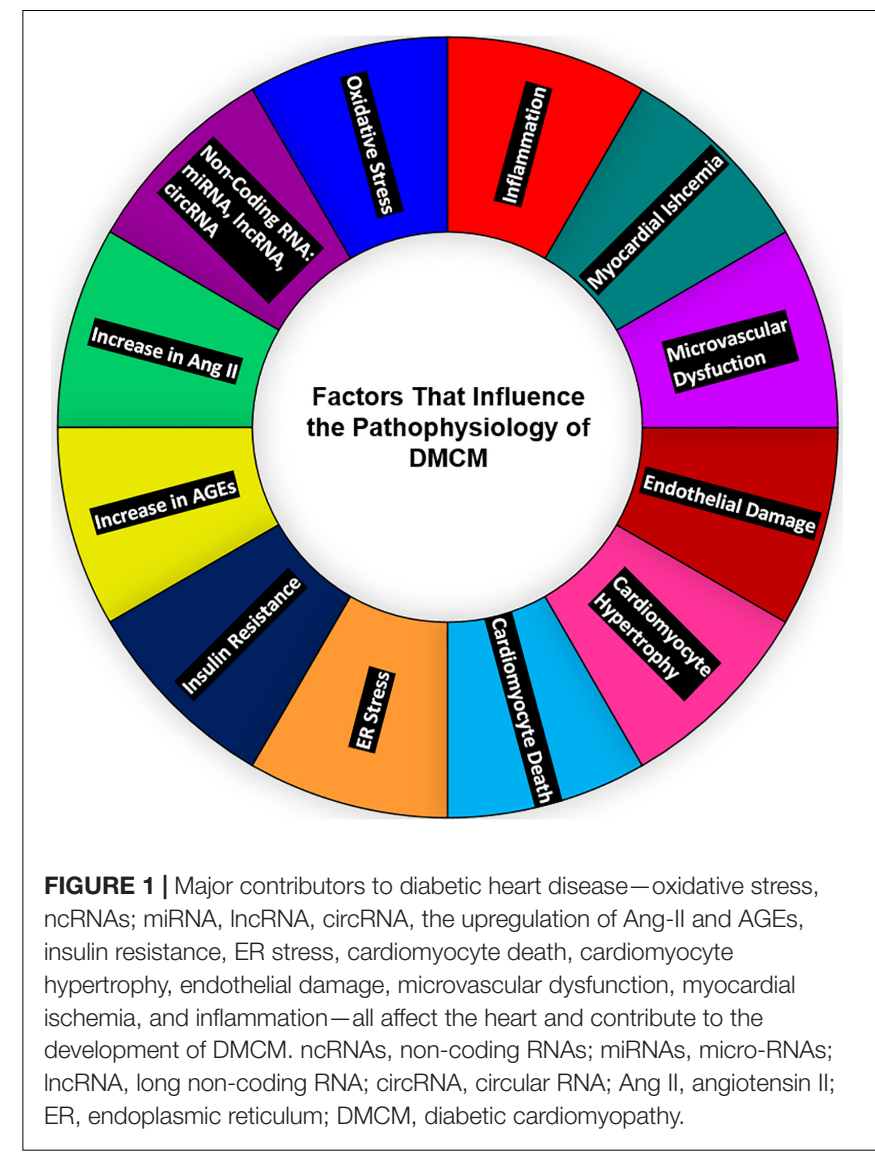

1972). The strong heart study showed that subjects of T2DM had statistically significant, 6-12\%, higher LV mass corrected for body surface area, inter-ventricular and posterior wall thickness, 5\% lower stress corrected mid-wall shortening, and arterial stiffness as demonstrated by a $13 \%$ increase in pulse pressure to stroke volume ratio (Devereux et al., 2000). Streptozotocin (STZ)induced diabetes in male Sprague-Dawley (SD)-derived rats, which led to lipid accumulation in the myocardium associated with a breach in myocardial integrity, characterized by the loss of contractile proteins, sarcoplasmic reticulum swelling, myocytolysis, the formation of myelin, and contractual bands (Jackson et al., 1985). There was a decrease in myosin ATPase enzyme in the myocardium, with the slow V3 electrocardiogram electrode isoform predominating as early as 2 weeks after the induction of diabetes (Malhotra et al., 1981). A $1 \mathrm{mmol} / \mathrm{L}$ increase in fasting plasma glucose was associated with a 1.23fold increase in risk for hospitalization for HF (Held et al., 2007). Rising glycosylated hemoglobin was associated with a higher hospitalization rate for $\mathrm{HF}$ in middle-aged subjects without diabetes (HbAlc 5.5-6\%), implicating that $\mathrm{HF}$ begins even before the development of overt diabetes (Matsushita et al., 2010). Doppler studies showed diastolic dysfunction in up to $33 \%$ of young asymptomatic diabetic subjects (Zarich et al., 1988). Animal models provided insights that the presence of hypertension can aggravate the myocardial injury in rat models, evidenced by a greater heart weight to body weight ratio and 
severe interstitial fibrosis than diabetes or hypertension alone (Factor et al., 1981). Another study conducted in veterans with diabetes showed mortality to follow a U-shaped pattern with the achieved HbA1c level (7.1\% to 7.8\%) (Aguilar et al., 2009). In India, diabetes prevalence varies between $5 \%$ and $10 \%$ as per the gross domestic product of states, and a large proportion of patients $(47.3 \%)$ diagnosed with diabetes during the study were unaware of their diabetic status (Anjana et al., 2017). The maternal nutrition study conducted in India showed that the babies born in an unfavorable intrauterine environment are thinner and have smaller muscle mass and preserved subcutaneous fat than their European counterparts (Yajnik et al., 2003). A subsequent defect in calcium transportation in the isolated sarcoplasmic reticulum has been recorded in DMCM (Ganguly et al., 1983). While treatment with insulin showed reversibility of alterations in myocardial function, contractile protein biochemistry was as early as 10 days of therapy (Fein et al., 1984).

\section{THE TREATMENT APPROACH TO TYPE 1 DIABETES MELLITUS AND CARDIOMYOPATHY}

Type 1 diabetes mellitus (T1DM) is an autoimmune disease in which pancreatic $\beta$ cells that produce insulin are destroyed. The absence of $\beta$ cells/insulin impairs breakdown of sugar in the bloodstream and use it for energy (DiMeglio et al., 2018). Using STZ-induced diabetes rat models (Malhotra et al., 1981), Malhotra et al. (1981) showed the efficacy of intensive glycemic control in mitigating the structural and molecular changes in cardiomyopathy. Abnormal diastolic functioning correlated with glycemic control in T1DM subjects (Shishehbor et al., 2003). When T1DM subjects were intensively treated thrice or four times with insulin daily, the reduction of inflammatory markers was not reassuring (Schaumberg et al., 2005). There was a decrease in soluble intercellular adhesion molecule type 1 (sICAM). Still, soluble tumor necrosis factor- $\alpha$ receptor 1 (sTNR-R1) and high-sensitivity C-reactive protein (hs-CRP) had increased, especially in subjects who gained weight (Schaumberg et al., 2005). There was an improvement in LV echocardiographic parameters: peak lengthening rate, the peak wall thinning rate, $\mathrm{E} / \mathrm{A}$ ratio, and reduction in the $\mathrm{E}$ wave deceleration time (Grandi et al., 2002). Another study failed to replicate these findings but has found a reduction in LV mass and interventricular thickness irrespective of diabetic nephropathy (Aepfelbacher et al., 2004; Weinrauch et al., 2005; Grandi et al., 2006). The Diabetes Control and Complication Trial (DCCT)/Epidemiology of Diabetes Interventions and Complications (EDIC) study, aimed at intensive glycemic control in T1DM subjects, showed a significant reduction in any CV disease (CVD) by $30 \%$ and major CV events by $32 \%$ in the initial 6.5 years of follow-up. The effect on HF prevention was not specifically looked upon (Control and Trial, 2016). Angiotensin-converting enzyme (ACE) inhibitors effectively reduced mortality and prevented hospitalization for HF in T1DM (Lewis and Lewis, 2004). The SGLT2 inhibitors empagliflozin and ipragliflozin normalized the endothelium of
STZ-induced rat models, which may prove useful in human subjects if used along with a reasonable dosage of insulin (Oelze et al., 2014; Salim et al., 2016). Prospective randomized clinical trials are needed to assess whether this translates to clinical benefits.

\section{TYPE 2 DIABETES MELLITUS AND CARDIOMYOPATHY MANAGEMENT: EVIDENCE AND PROSPECTS}

Type 2 diabetes mellitus is a metabolic disorder, unlike T1DM. $\beta$ cells are not destroyed; they still produce insulin, but T2DM subjects are resistant and cannot respond to insulin (Fletcher et al., 2002). ACE inhibitors, angiotensin receptor blockers, aldosterone antagonists, spironolactone, and $\beta$ blockers are the most common medications used to treat HF in individuals with or without diabetes. The recent addition to the armamentarium is the valsartan/sacubitril combination. Valsartan-sacubitril, compared with enalapril, significantly prevented death due to CVD and all-cause mortality, while also reducing the number of hospitalizations for HF by $21 \%$ in subjects with reduced ejection fraction (PARADIGM-HF trial) (McMurray et al., 2014). However, it failed to achieve any significant benefits in subjects with pEF compared with valsartan alone (PARAGON-HF trial) (Solomon et al., 2019). High fasting plasma glucose and HbA1c predicted the rate of hospitalizations for HF in subjects with abnormal glucose regulation. Intensive glucose lowering with insulin and sulfonylureas did not improve the CV outcomes. Despite achieving adequate glycemic control, $\mathrm{HbA1c}$ reduction was not shown to be associated with improvement in $\mathrm{CV}$ mortality in the United Kingdom Prospective Diabetes Study (UKPDS) and the ADVANCE Collaborative Group trial (Group, 1998; Advance Collaborative Group, Patel et al., 2008). The 15-year follow-up study of the Veterans Affairs Diabetes Trial (VADT) showed no legacy effect of initial intensive glycemic control. This study showed prevention of CV events during the initial and prolonged phase of the study, but not in the long-term 15 years follow-up (Reaven et al., 2019). Another large meta-analysis of eight trials with 37,229 subjects showed that intensive glycemic control was not associated with lower incidences of HF (Castagno et al., 2011). Pioglitazone use was associated with a decline in significant CV events including stroke, fatal, and non-fatal myocardial infarction (MI), but it was associated with a higher incidence of HF due to renal sodium retention in the PROACTIVE study (Dormandy et al., 2005; Kernan et al., 2016). Though there was a higher incidence of edema in the IRIS study, subjects who experienced a stroke and had insulin resistance did not show an increased risk of HF (Dormandy et al., 2005; Kernan et al., 2016). Acarbose prevented new-onset diabetes, hypertension, and CV adverse events in subjects with IGT in the Study to Prevent Non-Insulin Dependent Diabetes (STOP-NIDD) but did not reduce the incidence of HF in the ACE study (Delorme and Chiasson, 2005; Holman et al., 2017b). Metformin improved passive stiffness of the LV chamber and preserved exercise capacity in rat models experiencing HF with pEF (HFpEF) (Slater et al., 2019). 
A recent retrospective study conducted in Taiwan revealed that metformin usage in T2DM was associated with a $40 \%$ decrease in hospital admissions for HF (Tseng, 2019). A metaanalysis of 40 studies by Han et al. (2019), comprising more than 10,000,000 subjects, showed that metformin use for MI and $\mathrm{HF}$ was associated with reduced mortality. The incidence of $\mathrm{CV}$ events in $\mathrm{HF}$ was also reduced (adjusted hazard ratio: $0.79 / 0.83 / 0.84$, respectively) in subjects with diabetes, but not in subjects without diabetes (Han et al., 2019). The activation of AMP kinase (AMPK) by metformin was shown to inhibit the TNF- $\alpha$ expression. The upregulation of the ABCG1 gene attenuates the conversion of a monocyte-macrophage into a foam cell (Hattori et al., 2006; Isoda et al., 2006); knockdown of AMPK- $\alpha$ abolishes this anti-inflammatory effect of metformin. AMPK activation prevents cardiac hypertrophy predominantly by inhibiting O-GlcNAcylation of cardiac troponin $\mathrm{T}$ when inhibiting the phosphorylation of the same glutamine:fructose6-phosphate aminotransferase enzyme (GFAT) (Gélinas et al., 2018). DPP4 inhibitor saxagliptin (SAVOR-TIMI 53) increased hospitalization for HF in patients with diabetes and established CVD or multiple $\mathrm{CV}$ risk factors. While sitagliptin (TECOS), alogliptin (EXAMINE), and linagliptin (CARMELINA) were all found to be safe, with regard to HF (Packer, 2018). DDP4 inhibition causes sympathetic nervous system overactivity via enhanced stromal cell-derived factor-1 (SDF-1), neuropeptide Y, and substance P leading to myocyte apoptosis (Packer, 2018). Though DPP4 inhibitors have received a green signal, these studies give a cautionary notice to clinicians. At the same time, they opt for this class of medications, especially in subjects with a high risk for HF.

In small-scale studies, glucagon-like peptide 1 (GLP-1) analog infusion was associated with improved LV function in $\mathrm{HF}$ subjects. The LEADER trial showed a non-significant, 13\% reduction in HF hospitalizations, but the FIGHT trial did not offer post-admission stability in subjects admitted with $\mathrm{HF}$ and reduced ejection fraction (Margulies et al., 2016; Marso et al., 2016b). Experimental studies showed liraglutide could render energy-deprived cardiomyocytes and lead to cardiac function deterioration (Shiraki et al., 2019). However, in clinical trials, GLP-1 agonists dulaglutide, albiglutide, and injectable/oral semaglutide showed a significant reduction of $\mathrm{CV}$ events than did the placebo (Marso et al., 2016a; Hernandez et al., 2018; Gerstein et al., 2019; Husain et al., 2019). Lixisenatide and weekly exenatide did not show any CV beneficial advantage over the placebo (Pfeffer et al., 2015; Holman et al., 2017a).

Recent evidence suggests the use of novel dual glucosedependent insulinotropic polypeptide (GIP) and GLP-1 receptor agonist play a beneficial role in patients of T2DM (Holst and Rosenkilde, 2020). In pre-clinical trials, LY3298176, a novel dual GIP and GLP-1 receptor agonist, demonstrated activation of both receptors (GIP and GLP-1) led to insulin secretion. In vivo study revealed glucose tolerance and reduced body weight and food intake in GLP-1R and GIPR null C57BL/6 mice. These cumulative effects were significantly higher with the comparison GLP-1 agonist alone, suggesting that activation of both GIP and GLP-1 receptors is crucial for controlling blood glucose level and body weight. Further, Coskun et al. (2018) performed a phase 1 clinical trial using LY3298176 on T2DM patients and found a significant decrease in fasting blood glucose.

Further, the same group took the drug LY3298176 to a phase 2 clinical trial and found better management of glucose levels and significant weight loss in T2DM patients than dulaglutide (Frias et al., 2018). These results highlight a novel dual incretin receptor agonist's promising role as a better drug candidate in managing T2DM patients. Future studies are warranted to validate this novel dual incretin receptor agonist in the management of DMCM.

The EMPA-REG outcome trial's dramatic results were that the SGLT2 inhibitor empagliflozin showed a 35\% reduction of HF in subjects with established CVD. This brought a paradigm shift in the management of glycemic control (Zinman et al., 2015). The CANVAS (canagliflozin) and the DECLARETIMI 58 (dapagliflozin) trial followed a similar decline in hospitalizations for HF in subjects with and without established CVD (Neal et al., 2017; Wiviott et al., 2019). The HF trials done subsequently in subjects with or without diabetes showed a statistically significant, 25\% reduction in HF hospitalization, with reduced ejection fraction by empagliflozin (EMPEROR-REDUCED trial) (McMurray et al., 2019). The study subjects had severe LV dysfunction and were on optimal anti-failure medications, including aldosterone antagonists and neprilysin inhibitors. The DAPA-HF (dapagliflozin) trial (in which the enrolled subjects had a better median ejection fraction and were not on aldosterone antagonists nor neprilysin inhibitors) also showed a reduction in HF events irrespective of their diabetic status (Packer et al., 2020). SGLT2 inhibitors are more promising than any other medication group in managing diabetes and HF's deadly duo. The key mechanism by which SGLT2 inhibitors modifies HF risk is that they bind the sodium binding sites of sodium-hydrogen exchanger (NHE-1) and attenuate the cytosolic sodium and calcium, improving calcium concentration in the sarcoplasmic reticulum (Uthman et al., 2018). Dapagliflozin attenuates inflammasome NRLP3, mediates inflammation, and improves hyperglycemia-induced LV dysfunction in mouse models (Ye et al., 2017).

SGLT1 is a vital transporter of glucose in the myocardium, and its overexpression was associated with pathologic cardiac hypertrophy, while its knockdown attenuated cardiomyopathy in PRKAG2 knockout murine models (Banerjee et al., 2009; Ramratnam et al., 2014). In db/db mice models, the SGLT1 inhibitor, phlorizin, preserved the typical cardiac structure (Cai et al., 2013). The first dual SGLT1 and SGLT2 blocker, sotagliflozin, improves postprandial glucose in patients with diabetes (Powell et al., 2020). Whether sotagliflozin and similar molecules will have an added advantage over selective SGLT2 inhibitors in the prevention and management of DMCM needs to be further investigated (Table 1).

Overall, future studies should identify a potential pharmacological agent that improves insulin resistance and $\beta$ cell dysfunction, does not induce hypoglycemia, attenuates inflammation, and improves the myocardium's fuel kinetics. This strategy seems to be the brightest potential in preventing DMCM. Further, that pharmacological agent should not activate 
TABLE 1 | List of clinical trials associated with treatment of DMCM.

\begin{tabular}{|c|c|c|c|c|c|c|c|}
\hline $\begin{array}{l}\text { Name of the } \\
\text { trial (number } \\
\text { of subjects) }\end{array}$ & $\begin{array}{l}\text { Molecule studied (dose } \\
\text { and route of } \\
\text { administration) }\end{array}$ & $\begin{array}{l}\text { MACE HR } \\
\text { (Cl/p value) }\end{array}$ & CV death & $\begin{array}{l}\text { Heart failure } \\
\text { HR }(95 \% \mathrm{Cl})\end{array}$ & Outcomes & Limitations of study & References \\
\hline $\begin{array}{l}\text { PARADIGM-HF } \\
\text { (8442) }\end{array}$ & $\begin{array}{l}\text { LCZ696 (200 mg twice } \\
\text { daily) and enalapril (10 mg } \\
\text { daily) }\end{array}$ & $\begin{array}{c}0.80 \\
(0.73-0.87) \\
p<0.001\end{array}$ & $\begin{array}{c}0.80 \\
(0.71-0.89) \\
p<0.001\end{array}$ & $\begin{array}{c}0.79 \\
(0.71-0.89) \\
p<0.001\end{array}$ & $\begin{array}{l}\text { LCZ696 performed better in } \\
\text { comparison of enalapril to reduce risk of } \\
\text { death and hospitalization in heart failure }\end{array}$ & $\begin{array}{l}\text { LCZ696 showed the hypotension in } \\
\text { patients }\end{array}$ & $\begin{array}{l}\text { McMurray et al. } \\
\text { (2014) }\end{array}$ \\
\hline $\begin{array}{l}\text { PARAGON-HF } \\
\text { (4822) }\end{array}$ & $\begin{array}{l}\text { Sacubitril-valsartan ( } 97 \mathrm{mg} \\
\text { sacubitril and } 103 \mathrm{mg} \\
\text { valsartan twice daily) and } \\
\text { valsartan (160 mg twice } \\
\text { daily) }\end{array}$ & $\begin{array}{c}0.87 \\
(0.75-1.01)\end{array}$ & $\begin{array}{c}0.95 \\
(0.79-1.16)\end{array}$ & $\begin{array}{c}0.85 \\
(0.72-1.00)\end{array}$ & $\begin{array}{l}\text { Sacubitril-valsartan did not significantly } \\
\text { lowered the risk of death due to HF and } \\
\text { hospitalization in heart failure }\end{array}$ & $\begin{array}{l}\text { Did not shown any cardiovascular } \\
\text { benefits in patients of heart failure with } \\
\text { preserved ejection fraction }\end{array}$ & $\begin{array}{l}\text { Solomon et al. } \\
\text { (2019) }\end{array}$ \\
\hline $\begin{array}{l}\text { PROACTIVE } \\
\text { STUDY (5238) }\end{array}$ & $\begin{array}{l}\text { Pioglitazone (15-45 mg } \\
\text { orally OD) }\end{array}$ & $\begin{array}{c}0.96 \\
(0.78-1.18)\end{array}$ & NA & NA & $\begin{array}{l}\text { Reduced the all kind of mortality } \\
\text { including non-fatal Ml and stroke in } \\
\text { T2DM patients }\end{array}$ & NA & $\begin{array}{l}\text { Dormandy et al. } \\
\text { (2005) }\end{array}$ \\
\hline LEADER (9340) & Liraglutide (1.8 mg s/c OD) & $\begin{array}{c}0.87 \\
(0.78-0.97) \\
p<0.015\end{array}$ & $\begin{array}{c}0.78 \\
(0.66-0.93) \\
p<0.007\end{array}$ & $\begin{array}{c}0.87 \\
(0.73-1.05) \\
p<0.14\end{array}$ & $\begin{array}{l}\text { Liraglutide reduces the event of death } \\
\text { due to cardiovascular causes and } \\
\text { non-fatal stroke T2DM patients with the } \\
\text { comparison of placebo group }\end{array}$ & $\begin{array}{l}\text { Safety and efficacy data need further } \\
\text { validation due to short time period of } \\
\text { study on patients ( } 3.5-5 \text { years study) }\end{array}$ & $\begin{array}{l}\text { Marso et al. } \\
(2016 b)\end{array}$ \\
\hline $\begin{array}{l}\text { SUSTAIN-6 } \\
(3297)\end{array}$ & $\begin{array}{l}\text { Semaglutide ( } 0.5 \text { or } 1 \mathrm{mg} \\
\text { s/c per week) }\end{array}$ & $\begin{array}{c}0.74 \\
(0.58-0.95) \\
p<0.016\end{array}$ & $\begin{array}{c}0.98 \\
(0.65-1.48) \\
p<0.92\end{array}$ & $\begin{array}{c}1.11 \\
(0.77-1.61) \\
p<0.57\end{array}$ & $\begin{array}{l}\text { Semaglutide significantly reduces the } \\
\text { event of cardiovascular death and } \\
\text { non-fatal Ml in patients of T2DM with } \\
\text { the placebo group }\end{array}$ & $\begin{array}{l}\text { Patients were studied for shorter time } \\
\text { period ( } 2.1 \text { years) and events of } \\
\text { gastrointestinal abnormality reported }\end{array}$ & $\begin{array}{l}\text { Marso et al. } \\
(2016 a)\end{array}$ \\
\hline $\begin{array}{l}\text { EXSCEL } \\
(14752)\end{array}$ & Exenatide (2 mg s/c weekly) & $\begin{array}{c}0.91 \\
(0.83-1.00) \\
p<0.061\end{array}$ & $\begin{array}{c}0.88 \\
(0.76-1.02) \\
p<0.096\end{array}$ & $\begin{array}{c}0.94 \\
(0.78-1.13)\end{array}$ & $\begin{array}{l}\text { No significant difference in key adverse } \\
\text { cardiovascular occurrence in both } \\
\text { groups (exenatide vs. placebo) }\end{array}$ & $\begin{array}{l}\text { Loss to follow up rate was high. First } \\
\text { generation injection device was } \\
\text { complex. There was no run-in period } \\
\text { determined by researcher. Not a } \\
\text { standardized method of care }\end{array}$ & $\begin{array}{l}\text { Holman et al. } \\
\text { (2017a) }\end{array}$ \\
\hline $\begin{array}{l}\text { Harmony } \\
\text { outcomes } \\
\text { (9463) }\end{array}$ & $\begin{array}{l}\text { Albiglutide (30 or } 50 \mathrm{mg} \mathrm{s} / \mathrm{c} \\
\text { weekly) }\end{array}$ & $\begin{array}{c}0.78 \\
(0.68-0.90) \\
p<0.0001\end{array}$ & $\begin{array}{c}0.93 \\
(0.73-1.19) \\
p<0.58\end{array}$ & $\begin{array}{c}0.85 \\
(0.70-1.04) \\
p<0.113\end{array}$ & $\begin{array}{l}\text { Reduced the potential of CV } \\
\text { complications. Improved cardiovascular } \\
\text { outcomes for T2DM patients. }\end{array}$ & $\begin{array}{l}\text { Short follow up. } 25 \% \text { of participants } \\
\text { discontinued the study prior to } \\
\text { completion. Microvascular } \\
\text { complications were not noted. Urinary } \\
\text { albumin excretion and lipids were no } \\
\text { measured. }\end{array}$ & $\begin{array}{l}\text { Hernandez } \\
\text { et al. (2018) }\end{array}$ \\
\hline
\end{tabular}


TABLE 1 | Continued

\begin{tabular}{|c|c|c|c|c|c|c|c|}
\hline $\begin{array}{l}\text { Name of the } \\
\text { trial (number } \\
\text { of subjects) }\end{array}$ & $\begin{array}{l}\text { Molecule studied (dose } \\
\text { and route of } \\
\text { administration) }\end{array}$ & $\begin{array}{l}\text { MACE HR } \\
\text { (Cl/p value) }\end{array}$ & CV death & $\begin{array}{l}\text { Heart failure } \\
\text { HR }(95 \% \mathrm{Cl})\end{array}$ & Outcomes & Limitations of study & References \\
\hline REWIND (9901) & $\begin{array}{l}\text { Dulaglutide (1.5 mg per } \\
\text { week s/c) }\end{array}$ & $\begin{array}{c}0.88 \\
(0.79-0.99) \\
p<0.026\end{array}$ & $\begin{array}{c}0.91 \\
(0.78-1.06) \\
p<0.21\end{array}$ & $\begin{array}{c}0.93 \\
(0.77-1.12) \\
p<0.46\end{array}$ & $\begin{array}{l}\text { Lowers CV outcomes within } 5 \text { years. } \\
\text { Lowers blood pressure. Increases } \\
\text { weight loss. Lowers glucose levels } \\
\text { while preventing risk of hypoglycemia }\end{array}$ & $\begin{array}{l}\text { Over } 25 \% \text { of participants stopped using } \\
\text { dulaglutide before study was } \\
\text { completed. }\end{array}$ & $\begin{array}{l}\text { Gerstein et al. } \\
\text { (2019) }\end{array}$ \\
\hline $\begin{array}{l}\text { EMPA-REG } \\
(7020)\end{array}$ & $\begin{array}{l}\text { Empagliflozin (10-25 mg } \\
\text { once daily) }\end{array}$ & $\begin{array}{c}0.86 \\
(0.74-0.99)\end{array}$ & $\begin{array}{c}0.62 \\
(0.49-0.77) \\
p<0.001\end{array}$ & $\begin{array}{c}0.65(0.5-0.85) \\
p<0.002\end{array}$ & $\begin{array}{l}\text { Lowered the rate of primary composite } \\
\mathrm{CV} \text { outcome and death from any cause } \\
\text { when studying the drug added to } \\
\text { standard care }\end{array}$ & $\begin{array}{l}\text { The discontinuation rate of both groups } \\
\text { very similar }\end{array}$ & $\begin{array}{l}\text { Zinman et al. } \\
\text { (2015) }\end{array}$ \\
\hline $\begin{array}{l}\text { DAPA-HF } \\
(4744)\end{array}$ & $\begin{array}{l}\text { Dapagliflozin (10 mg once } \\
\text { daily) }\end{array}$ & $\begin{array}{c}0.74 \\
(0.65-0.85) \\
p<0.001\end{array}$ & $\begin{array}{c}0.82 \\
(0.69-0.98)\end{array}$ & $\begin{array}{c}0.70 \\
(0.59-0.83)\end{array}$ & $\begin{array}{l}\text { Reduces the risk of worsening } \mathrm{CV} \\
\text { conditions compared to the placebo. } \\
\text { The adverse event rate did not differ }\end{array}$ & $\begin{array}{l}\text { Inclusion and exclusion criteria were } \\
\text { very particular which could have } \\
\text { decreased the generalizability of the } \\
\text { study. The study also had limited } \\
\text { diversity, also lowering generalizability }\end{array}$ & $\begin{array}{l}\text { McMurray et al. } \\
\text { (2019) }\end{array}$ \\
\hline $\begin{array}{l}\text { CANVAS } \\
\text { PROGRAM } \\
\text { (10142) }\end{array}$ & $\begin{array}{l}\text { Canagliflozin ( } 100 \mathrm{mg} \text { and } \\
300 \mathrm{mg} \text { orally daily) }\end{array}$ & $\begin{array}{c}0.86 \\
(0.75-0.97) \\
p<0.60\end{array}$ & $0.9(0.7-1.15)$ & $\begin{array}{c}0.67 \\
(0.52-0.87)\end{array}$ & $\begin{array}{l}\text { Decreases risk of mortality from CV } \\
\text { complication, non-fatal MI and non-fatal } \\
\text { stroke. Increased risk of amputation }\end{array}$ & $\begin{array}{l}\text { Low levels of end-stage renal disease. } \\
\text { Increase use of glucose-lowering } \\
\text { solutions in the placebo group may } \\
\text { have resulted in risks or benefits of } \\
\text { Canagliflozin }\end{array}$ & $\begin{array}{l}\text { Neal et al. } \\
(2017)\end{array}$ \\
\hline $\begin{array}{l}\text { EMPEROR- } \\
\text { reduced } \\
\text { (3730) }\end{array}$ & Empagliflozin (10 mg daily) & $\begin{array}{c}0.75 \\
(0.65-0.86) \\
p<0.001\end{array}$ & $\begin{array}{c}0.92 \\
(0.75-1.12)\end{array}$ & $\begin{array}{c}0.69 \\
(0.59-0.81)\end{array}$ & $\begin{array}{l}\text { Reduction in the risk of CV death or } \\
\text { hospitalization for HF compared to the } \\
\text { placebo. Slower progression of renal } \\
\text { failure with chronic } \mathrm{HF} \text { and reduced } \\
\text { ejection fraction. }\end{array}$ & $\begin{array}{l}\text { Uncomplicated genital tract infection } \\
\text { was found higher in empagliflozin } \\
\text { treated group }\end{array}$ & $\begin{array}{l}\text { Packer et al. } \\
(2020)\end{array}$ \\
\hline $\begin{array}{l}\text { DECLARE-TIMI } \\
58(17,160)\end{array}$ & Dapagliflozin (10 mg daily) & $\begin{array}{c}0.93 \\
(0.84-1.03) \\
p<0.17\end{array}$ & $\begin{array}{c}0.98 \\
(0.82-1.17)\end{array}$ & $\begin{array}{c}0.73 \\
(0.61-0.88)\end{array}$ & $\begin{array}{l}\text { Reduction in the hospitalization of the } \\
\text { patients with heart failure }\end{array}$ & $\begin{array}{l}\text { Genital tract infection were higher in } \\
\text { treated groups that leads to } \\
\text { discontinuation of study }\end{array}$ & $\begin{array}{l}\text { Wiviott et al. } \\
\text { (2019) }\end{array}$ \\
\hline
\end{tabular}

MACE, major adverse cardiovascular events; HR, hazard ratio; Cl, confidence interval; CV, cardiovascular; mg, milligram; s/c, sub-cutaneous; OD, once daily; T2DM, type 2 diabetes mellitus; MI, myocardial infarction;

$H F$, heart failure; NA, not applicable. 
renin-angiotensin or the sympathetic nervous system. Thus, a comprehensive treatment plan is of utmost importance.

\section{Role of Non-coding RNAs in Diabetic Cardiomyopathy}

Diabetic cardiomyopathy can be characterized by many events such as mitochondrial dysfunction, inflammation, oxidative stress, apoptosis, autophagy, microangiopathy, and myocardial metabolic abnormalities (Tan et al., 2020). However, no existent approaches efficiently limit/reduce the development of DMCM (Table 2) (Swedberg et al., 2010; Insulin, 2012; Eurich et al., 2013; Green et al., 2015; Zinman et al., 2015; Ponikowski et al., 2016; Jorsal et al., 2017; Garber et al., 2018). Despite development in controlling glycemic levels, $\mathrm{CV}$ events in diabetic patients significantly burden patients' health-care costs, quality of life, and mortality (Borghetti et al., 2018). This emphasizes a need for novel diagnostics, more understanding of underlying mechanisms, and new therapeutic strategies.

Emerging evidence suggests that non-coding regions of the human genome have a significant role in the health and disease pathophysiology (Esteller, 2011). So far, in the human genome, well-studied sequences are protein-coding genes, which account for only $1.5-2 \%$ of the total genome, while the majority of the genome is shared by the non-coding RNAs (ncRNAs). The majority of ncRNAs can be categorized into small and long ncRNA (lncRNA) (Zhang et al., 2019). This review focuses on the role of micro-RNAs (miRNAs), lncRNAs, and circular RNAs (circRNAs) in the DMCM (Figure 2 and Table 3 ).

\section{Micro-RNAs in Diabetic Cardiomyopathy}

Micro-RNA consists of highly conserved, single-stranded ncRNAs and range 16-27 nucleotides in length (Wahid et al., 2010; Fang et al., 2013; Joladarashi et al., 2015; Verma et al., 2017a,b; Lu and Rothenberg, 2018). They were first reported in nematode Caenorhabditis elegans (Lee et al., 1993). Biogenesis of miRNA is regulated by two nuclear ribonuclease III (RNase III) proteins, i.e., Drosha and Dicer. At the transcriptional level, miRNA's biogenesis is regulated by Drosha, which cleaves the pre-miRNA and releases approximately 70-100 nucleotides of precursor miRNAs. After its transportation to the cytoplasm, Dicer cleaves the precursor and forms a mature miRNA. A significant function of miRNAs is to modulate transcription and translation programs (Ha and Kim, 2014).

Recent studies highlight a key role for miRNAs in cardiac disease (Van Rooij et al., 2008; Guo and Nair, 2017). Another study on cardiac myocytes demonstrated that the overexpression of miRNA-133 inhibits GLUT4 expression and suppresses the insulin-stimulated glucose uptake (Horie et al., 2009). Another study identified miR-200b regulating endothelial to mesenchymal transition (End MT) in mouse models of DMCM (Feng et al., 2016). Liu et al. (2014) demonstrated that cardiac fibroblasts subjected to hyperglycemic conditions (30 $\mathrm{mM})$ exhibited an increase in miR-21 levels, further showing that increased miR-21 levels promoted collagen synthesis by targeting dualspecificity phosphatase 8 (DUSP8). Another study by Feng et al. (2010) performed on STZ-induced T1DM mouse models demonstrated significantly reduced levels of miR-133a in cardiac tissue. MiR-133a is an enriched muscle and has a role in muscle development and cellular differentiation (Liang et al., 2007). Chen et al. (2014) reported the involvement of miR133a in diabetes-induced cardiac fibrosis, finding significant repression of miR-133a in the STZ-induced diabetic hearts, whereas the major markers of fibrosis [fibronectin 1 (FN1), tumor growth factor- $\beta$ (TGF- $\beta$ ), and connective tissue growth factor] were found to be higher. Another study performed by Nandi et al. (2016) revealed the involvement of miR133a in diabetic heart disease. They have shown miR-133a to mimic treatment in STZ rats, improving contractility of heart with subsequent upregulation of tyrosine hydroxylase, norepinephrine, and $\beta$-adrenergic receptor (Nandi et al., 2016). MiR-200c played an important role in cardiac hypertrophy and was found significantly higher in diabetic hearts. In diabetesassociated cardiac hypertrophy, a higher expression of miR$200 \mathrm{c}$ is reported, which negatively regulates the expression of dual-specificity phosphatase-1 (DUSP-1) (Singh et al., 2017). However, the miR-200c inhibition improves the level of DUSP-1 via suppressing the expression of the phosphorylated extracellular signal-regulated kinase (ERK), c-Jun $\mathrm{N}$-terminal kinases (JNKs), and p38, further improving cardiac hypertrophy in high glucose (HG)-treated $(30 \mathrm{mmol} / \mathrm{L})$ rat cardiomyocytes (Singh et al., 2017). Recent findings by Tao et al. (2020) reveal the role of miR-144 in the protection of the diabetic heart by regulating cardiomyocyte apoptosis, displaying that miR-144 was found to be significantly decreased in HGtreated cardiomyocytes and in the heart of STZ-induced diabetic mice, which were associated with mitochondrial dysfunction and cell death. However, the overexpression of miR144 ameliorates the mitochondrial dysfunction and negatively regulates cell death (Tao et al., 2020). Xu et al. (2020) established the role of miR-223 in DMCM. Cardiomyocytes subjected to HG showed elevated miR-223 levels. Further inhibition of miR-223 rescued the myocardial apoptosis and fibrosis by suppressing the expression NLRP3 inflammasome (Xu et al., 2020). Interestingly, Tang et al. (2018) showed the involvement of miR-22 in amelioration of DMCM. The overexpression of miR-22 reduced oxidative stress in DMCM by targeting sirtuin-1 (Tang et al., 2018). Using a high-fatdiet (HFD) mouse model, Copier et al. (2017) showed at 16 months that circulating miRNA (miR-19b-3p and miR-181b$5 p)$ levels correlated with the development of cardiomyopathy. Furthermore, this study established miR-19b and miR-181b as potential biomarkers for DMCM. A recent study performed on myocardial microvascular endothelial cells (MMECs) from T2DM Goto-Kakizaki rats showed that miRNA-193-5p plays an important role as an angiogenic factor in DMCM by negatively regulating the expression of insulin growth factor2 (IGF-2) (Yi et al., 2017). In another very intriguing study performed by Kuwabara et al. (2015), in HFD-fed C57BL/6 T2DM rat model, the expression of miRNA-451 levels was high in the myocardium. Further, cardiomyocyte-specific knockout of miRNA-451 led to an improvement in cardiac hypertrophy response compared with control mice. This finding established the potential role of miRNA-451 in DMCM by suppressing 
TABLE 2 | Current therapies of DMCM.

\begin{tabular}{|c|c|c|c|}
\hline Category of drug & Name & Mode of action & References \\
\hline Biguanides & Metformin & $\begin{array}{l}\text { Controls the blood glucose levels by activating the AMPK } \\
\text { pathway }\end{array}$ & $\begin{array}{l}\text { Eurich et al. (2013) and } \\
\text { Garber et al. (2018) }\end{array}$ \\
\hline Insulin & Humulin & $\begin{array}{l}\text { Increases glucose uptake in insulin sensitive tissues and } \\
\text { lowers peripheral blood glucose }\end{array}$ & Insulin (2012) \\
\hline $\begin{array}{l}\text { Angiotensin-converting } \\
\text { enzyme inhibitor }\end{array}$ & Ramipril & angiotensin convertase enzyme inhibitor (ACE-i) & Ponikowski et al. (2016) \\
\hline $\begin{array}{l}\text { Angiotensin receptor } \\
\text { neprilysin inhibitor }\end{array}$ & Sacubitril/Valsartan & angiotensin II receptor blocker/neprilysin inhibitor & Ponikowski et al. (2016) \\
\hline Ivabradine & & $\begin{array}{l}\text { Decreases the heart rate by suppressing the } \mathrm{l}_{f} \text { channel in } \\
\text { the sinus node }\end{array}$ & Swedberg et al. (2010) \\
\hline DPP4 inhibitor & Sitagliptin & Blocks the enzyme DPP4 and stimulates insulin secretion & Green et al. (2015) \\
\hline GLP1 receptor agonist & Exenatide, Liraglutide & Release the insulin from pancreatic-beta cell & Jorsal et al. (2017) \\
\hline SGLT2 inhibitor & Empagliflozin & $\begin{array}{l}\text { Reduces blood glucose level by acting on kidney to remove } \\
\text { sugar from body to urine. }\end{array}$ & Zinman et al. (2015) \\
\hline
\end{tabular}

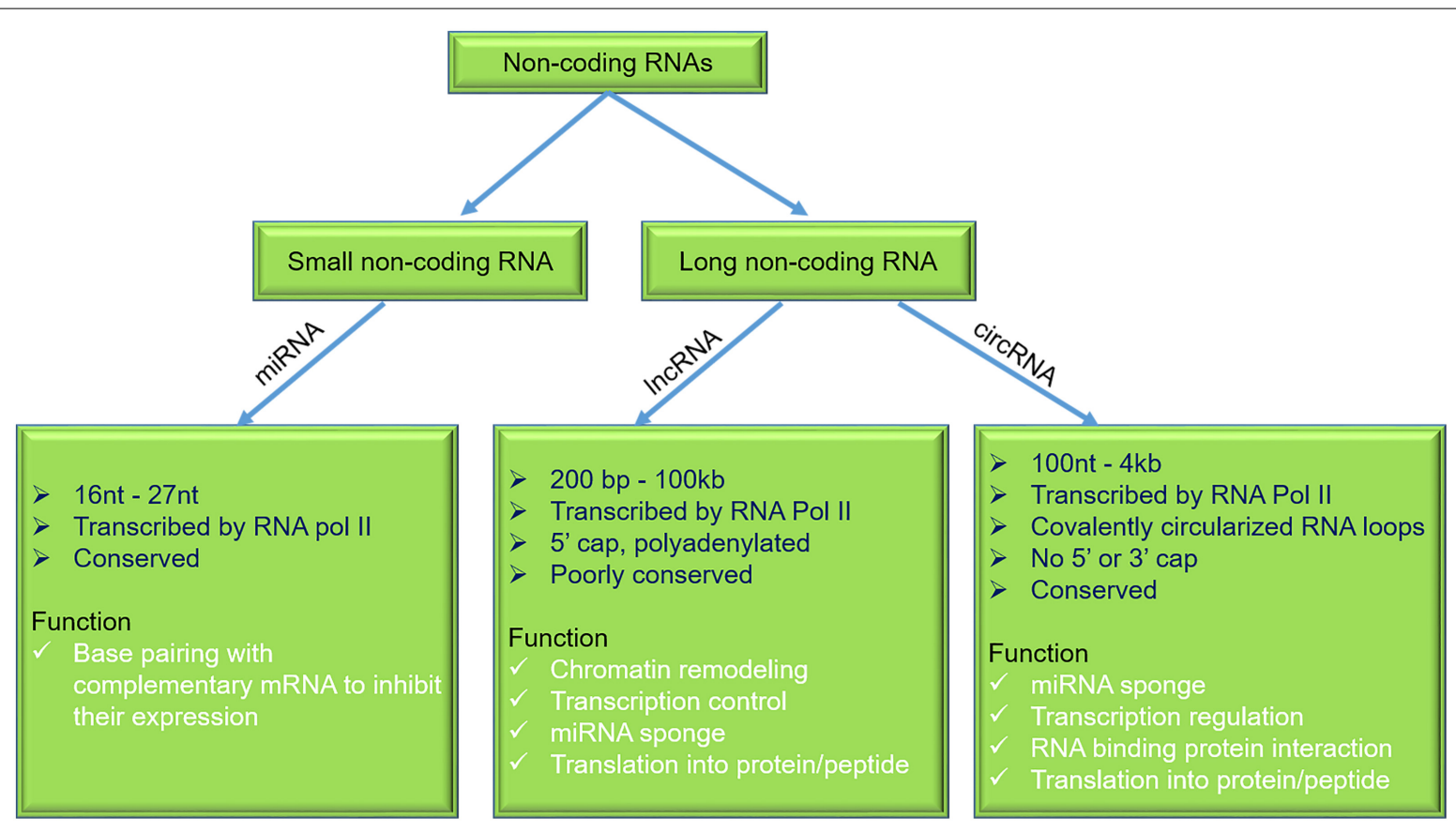

FIGURE 2 | General characteristics and functions of miRNAs, IncRNAs, and circRNAs. miRNAs, micro-RNAs; IncRNAs, long non-coding RNAs; circRNAs, circular RNAs.

the liver kinase B1 (LKB1)/AMP-activated protein kinase pathway (Kuwabara et al., 2015). A recent study highlighted the importance of miR-320 in DMCM (Li et al., 2019). In this study, the authors reported upregulation of miR-320 in the $\mathrm{db} / \mathrm{db}$ hearts and failing human hearts with pre-existing diabetes. To understand the functional role of miR-320, the authors performed gain and loss of miR-320 in $\mathrm{db} / \mathrm{db}$ mouse and observed that miR-320 silencing improved cardiac dysfunction (Li et al., 2019), whereas miR-320 overexpression worsened the cardiac phenotype. Mechanistically, miR-320 regulates transcription of fatty acid metabolic genes to rescue lipotoxicity in the diabetic heart (Li et al., 2019). In a similar line, an intriguing study by Lew et al. (2020) demonstrated that early exercise in diabetes mice (from 8 weeks) strikingly rescued the onset and progression of DMCM. Importantly noted, diabetic mice did not exhibit any functional benefits when the exercise was initiated after the establishment of cardiac dysfunction (at 16 weeks). Mechanistically, diabetic mouse hearts (16 weeks) with cardiac dysfunction exhibited repression of miRs, viz., miR-126 (proangiogenic), miR-499 (anti-angiogenic), miR-15a/b, and miR-133 (anti-fibrotic). The findings by Lew et al. (2020) suggest that a downregulation of these miRs leads to pathological remodeling in the diabetic heart. Interestingly, early exercise normalizes the aforementioned miR expression. Furthermore, silencing of miR-126 abrogated exercise-mediated rescue of DMCM. Overall, these results highlight the importance of 
TABLE 3 | Role of ncRNAs in diabetic cardiomyopathy.

\begin{tabular}{|c|c|c|c|c|c|}
\hline Source cell/animals & nc-RNA & Target delivery method & Targets & Outcome & References \\
\hline Cardiac myocytes & miR-133 & $\begin{array}{l}\text { Lentivirus induced transduction } \\
\text { (in vitro) }\end{array}$ & Inhibits GLUT4 via KLF15 & $\begin{array}{l}\text { Reduces insulin stimulated glucose } \\
\text { uptake in cardiomyocyte }\end{array}$ & Horie et al. (2009) \\
\hline $\begin{array}{l}\text { Cardiac microvascular endothelial } \\
\text { cells/diabetic mice }\end{array}$ & miR-200b & $\begin{array}{l}\text { miR-200b mimic or antagomir } \\
\text { (in vitro) }\end{array}$ & $\begin{array}{l}\text { VEGF, zinc finger } \\
\text { E-box-binding homeobox, } \\
\text { TGF- } \beta 1 \text {, and p300 }\end{array}$ & $\begin{array}{l}\text { Prevents diabetes induced changes } \\
\text { in structure and function of heart }\end{array}$ & Feng et al. (2016) \\
\hline Primary cardiac fibroblasts & miR-21 & $\begin{array}{l}\text { miR-21 mimic/miR-21 inhibitor } \\
\text { (in vitro) }\end{array}$ & Dual specific phosphatase8 & $\begin{array}{l}\text { Promotes HG induced cardiac } \\
\text { fibrosis }\end{array}$ & Liu et al. (2014) \\
\hline HG treated cardiomyocyte & miR-133a & miR-133a mimic (in vitro) & SGK1, IGF1R and MEF2 & $\begin{array}{l}\text { Prevents HG induced } \\
\text { cardiomyocyte hypertrophy }\end{array}$ & Feng et al. (2010) \\
\hline $\begin{array}{l}\text { STZ-induced diabetic mice } \\
\text { (miR-133a Tg mice) }\end{array}$ & $m i R-133 a$ & $\begin{array}{l}\text { miR-133a Tg mice (over expression } \\
\text { in heart) }\end{array}$ & $\begin{array}{l}\text { EP300, TGF- } \beta \text {, FN1 and } \\
\text { COL4A1 }\end{array}$ & $\begin{array}{l}\text { Prevents diabetes induced cardiac } \\
\text { fibrosis }\end{array}$ & Chen et al. (2014) \\
\hline $\begin{array}{l}\text { STZ induced SD rats/miR-133a Tg } \\
\text { mice }\end{array}$ & $\mathrm{miR}-133 \mathrm{a}$ & $\begin{array}{l}\text { Lentivirus mediated } \\
\text { miR-133a/anti-miR-133a (in vivo) }\end{array}$ & $\begin{array}{l}\text { Tyrosine aminotransferase and } \\
\text { tyrosine hydroxylase }\end{array}$ & Increases contractility of heart & Nandi et al. (2016) \\
\hline $\begin{array}{l}\mathrm{HG} \text { treated neonatal rat } \\
\text { cardiomyocyte }\end{array}$ & miR-200c & miR-200c inhibitor (in vitro) & DUSP1, JNK1, ERK and p38 & Increases cardiac hypertrophy & Singh et al. (2017) \\
\hline $\begin{array}{l}\text { HG treated cardiomyocyte and STZ } \\
\text { induced diabetic mice }\end{array}$ & miR-144 & $\begin{array}{l}\text { miR-144 mimic/miR-144 inhibitor } \\
\text { (in vitro and in vivo) }\end{array}$ & $\begin{array}{l}\text { Rac1, AMPK phosphorylation } \\
\text { and PGC-1 } \alpha\end{array}$ & Reduces cardiac apoptosis & Tao et al. (2020) \\
\hline $\begin{array}{l}\text { HG treated cardiomyocyte/STZ } \\
\text { treated SD rat }\end{array}$ & miR-223 & $\begin{array}{l}\text { miR-223 inhibitor (in vitro and } \\
\text { in vivo) }\end{array}$ & NLRP3 inflammasome & $\begin{array}{l}\text { Induces cardiac fibrosis and } \\
\text { apoptosis }\end{array}$ & Xu et al. (2020) \\
\hline $\begin{array}{l}\text { HG treated } \mathrm{H} 9 \mathrm{c} 2 \text { cells/STZ treated } \\
\text { mice fed HFD }\end{array}$ & mi-RNA 22 & $\begin{array}{l}\text { mi-RNA } 22 \text { overexpression by } \\
\text { intravenous injection of adenovirus } \\
\text { (in vivo) }\end{array}$ & Sirt1 & Attenuates oxidative stress & Tang et al. (2018) \\
\hline HFD fed mice & $\begin{array}{l}\text { miR-19b-3p, } \\
\text { miRNA181b-5p }\end{array}$ & NA & NA & Cardiac hypertrophy & Copier et al. (2017) \\
\hline MMEC of T2DM Goto-Kakizaki rats & miR-193-5p & miR-193-5p antagomir (in vitro) & IGF2 & Promotes angiogenesis & Yi et al. (2017) \\
\hline $\begin{array}{l}\text { Neonatal cardiac myocyte treated } \\
\text { with palmitic acid/HFD fed mice }\end{array}$ & miR-451 & $\begin{array}{l}\text { Cardiomyocyte-specific miR-451 } \\
\text { knockout mice }\end{array}$ & $\begin{array}{l}\text { LKB1/AMP activated protein } \\
\text { kinase pathway }\end{array}$ & $\begin{array}{l}\text { Promotes lipotoxicity in } \\
\text { cardiomyocyte and increases } \\
\text { cardiac hypertrophy }\end{array}$ & Kuwabara et al. (2015) \\
\hline $\mathrm{db} / \mathrm{db}$ mice and diabetic patients & miR-320 & $\begin{array}{l}\text { miR-320 mimic/miR-320 inhibitor } \\
\text { (in vitro and in vivo) }\end{array}$ & CD36 & Induces lipotoxicity in diabetic heart & Li et al. (2019) \\
\hline $\mathrm{db} / \mathrm{db}$ mice & $\begin{array}{l}\text { miR-126, } \\
\text { miR-499, } \\
\text { miR-15b }\end{array}$ & $\begin{array}{l}\text { miR-126 mimic and anti-miR-126 } \\
\text { (in vivo) }\end{array}$ & VEGF and SPRED-1 & $\begin{array}{l}\text { Increased coronary arterioles and } \\
\text { improved cardiac dysfunction }\end{array}$ & Lew et al. (2020) \\
\hline STZ induced diabetes in rats & $\begin{array}{l}\text { IncRNA- } \\
\text { MALAT1 }\end{array}$ & $\begin{array}{l}\text { Intracoronary injection with } \\
\text { lentivirus MALAT1 shRNA/scramble } \\
\text { shRNA (in vivo) }\end{array}$ & NA & $\begin{array}{l}\text { Induces cardiomyocyte } \\
\text { apoptosis/left ventricular function }\end{array}$ & Zhang et al. (2016) \\
\hline
\end{tabular}

(continued)


TABLE 3 | Continued

\begin{tabular}{|c|c|c|c|c|c|}
\hline Source cell/animals & nc-RNA & Target delivery method & Targets & Outcome & References \\
\hline $\begin{array}{l}\text { Cultured neonatal rat } \\
\text { cardiomyocyte/STZ treated rats }\end{array}$ & IncRNA- H19 & $\begin{array}{l}\text { Intracoronary injection with } \\
\text { lentivirus pcDNA-H19 (in vivo) }\end{array}$ & VDAC1 & $\begin{array}{l}\text { Suppresses cardiomyocyte } \\
\text { apoptosis }\end{array}$ & Li X. et al. (2016) \\
\hline $\begin{array}{l}\text { Mouse neonatal cardiac } \\
\text { fibroblast/HFD fed mice and also } \\
\text { STZ induced diabetes }\end{array}$ & IncRNA-Crnde & $\begin{array}{l}\text { Injected with AAV-Crnde or } \\
\text { AAV-shCrnde (in vivo) }\end{array}$ & Smad3 & Attenuates cardiac fibrosis & Zheng et al. (2019) \\
\hline $\begin{array}{l}\text { AC16/cardiomyocyte cells, STZ } \\
\text { induced diabetes }\end{array}$ & $\begin{array}{l}\text { IncRNA- } \\
\text { Kcnq1 ot1 }\end{array}$ & $\begin{array}{l}\text { si-Kcnq1ot1 and Kcnq1 ot1 } \\
\text { lentivirus-shRNA (in vitro and } \\
\text { in vivo) }\end{array}$ & miR-214-3p and caspase-1 & Promotes pyroptosis in DMCM & Yang et al. (2018) \\
\hline T2DM patients & $\begin{array}{l}\text { IncRNA- } \\
\text { LIPCAR, } \\
\text { SENCAR and } \\
\text { MIAT }\end{array}$ & NA & NA & Left ventricular diastolic function & $\begin{array}{l}\text { de Gonzalo-Calvo } \\
\text { (2016) }\end{array}$ \\
\hline $\begin{array}{l}\text { STZ treated mice/HG treated } \\
\text { primary cardiomyocyte }\end{array}$ & IncRNA-MIAT & $\begin{array}{l}\text { IncRNA-MIAT lentivirus or CASP1 } \\
\text { inhibitor/siMIAT (in vitro and in vivo) }\end{array}$ & miR-214-3p and IL-17 & $\begin{array}{l}\text { Promotes secretion of IL-17 and } \\
\text { induces cardiac fibrosis }\end{array}$ & Qi et al. (2020) \\
\hline $\begin{array}{l}\text { HG treated cardiomyocyte of newly } \\
\text { born mouse }\end{array}$ & IncRNA-Gas5 & shRNA -Gas5 (in vitro) & miR-320-3p and Tcf-3 & Promotes apoptosis & Su et al. (2020) \\
\hline $\begin{array}{l}\mathrm{HG} \text { treated } \mathrm{H} 9 \mathrm{c} 2 \text { cells and STZ } \\
\text { treated mice }\end{array}$ & $\begin{array}{l}\text { IncRNA- } \\
\text { HOTAIR }\end{array}$ & $\begin{array}{l}\text { Tail vein injection of AAV 2-HOTAIR } \\
\text { and Ad-sh-HOTAIR (in vitro and } \\
\text { in vivo) }\end{array}$ & miR-34 and Sirt1 & $\begin{array}{l}\text { Prevents cardiac inflammation, } \\
\text { oxidative injury and apoptosis }\end{array}$ & Gao et al. (2019) \\
\hline T2DM patients & $\begin{array}{l}\text { hsa- } \\
\text { circRNA11783- } \\
2\end{array}$ & NA & NA & Coronary artery diseases & Li et al. (2017) \\
\hline $\mathrm{db} / \mathrm{db}$ mice & circRNAs_00203 & rAd-circRNA_000203 (in vitro) & Col1a2 and CTGF, miR-26b-5p & $\begin{array}{l}\text { Enhances expression of fibrosis } \\
\text { associated genes }\end{array}$ & Tang et al. (2017) \\
\hline $\begin{array}{l}\text { HG treated cardiomyocytes/serum } \\
\text { of diabetic patients }\end{array}$ & hsa_circ_0076631 & $\begin{array}{l}\text { Anti-sense oligonucleotide for } \\
\text { hsa_circ_0076631 (in vitro) }\end{array}$ & miR-214-3p, caspase-1 & Induces pyroptosis & Yang et al. (2019) \\
\hline
\end{tabular}

ncRNA, non-coding RNA; miR, micro RNA; GLUT4, glucose transporter type 4; KLF15, Kruppel-like factor; HG, high glucose; STZ, streptozotocin; SGK1. serum- and glucocorticoid-regulated kinase 1; IGF1R, insulin-like growth factor-1 receptor; MEF2, myocyte enhancer factor-2; Tg mice, transgenic mice; FN1, fibronectin; COL $4 A 1$, collagen 1 alpha $1 V$; TGF- $\beta$, transforming growth factor- $\beta 1$; SD rats, Sprague-Dawley rats; DUSP1, dual-specific phosphatase-1; JNK1, jun-amino-terminal kinase 1; ERK, extracellular signal-related kinase; Rac1, Ras-related C3 botulinum toxin substrate 1; AMPK, AMP-activated protein kinase; PGC-1a, peroxisome proliferator-activated receptor gamma coactivator 1-alpha; NLRP3, NLR family pyrin domain containing 3; HFD, high fat diet; Sirt1, sirtuin1; MMEC, myocardial microvascular endothelial cells; T2DM, type 2 diabetes mellitus; IGF2, insulin-like growth factor 2; LKB1, liver kinase B1; CD36, cluster of differentiation 36; VEGF, vascular endothelial growth factor; SPRED-1, sprouty related EVH1 domain Containing 1; IncRNA, long non-coding RNA; MALAT1, metastasis associated lung adenocarcinoma transcript 1; Crnde, colorectal neoplasia differentially expressed; MIAT, myocardial infarction associated transcript; LIPCAR, Iong intergenic non-coding RNA predicting cardiac remodeling; shRNA, short hairpin RNA; VDAC1, voltage-dependent anion-selective channel 1; AAV, adeno associated virus; Smad3, mothers against decapentaplegic homolog 3; IL17, interleukin 17; Gas 5, growth arrest specific 5; Tcf 3, transcription factor 3; HOTAIR, HOX antisense intergenic RNA; Circ-RNA, circular RNA; Col1a2, collagen alpha-2(I); CTGF, connective tissue growth factor; NA, not available. 
physical exercise in protecting CV health in patients with diabetes (Lew et al., 2020).

\section{Long Non-coding RNAs in Diabetic Cardiomyopathy}

Long non-coding RNAs are a class of ncRNAs with wide range of lengths ranging from 200 to over $100 \mathrm{~kb}$ (Ulitsky and Bartel, 2013; Li J. et al., 2016; Kopp and Mendell, 2018; Palazzo and Koonin, 2020; Tariq et al., 2020). LncRNAs can be classified into (a) stand-alone RNAs, (b) antisense transcripts, (c) long intron ncRNAs, (d) pseudogenes containing lncRNA, and (e) other lncRNAs with divergent transcripts. LncRNAs can be found in the nucleus and cytosol. They participate in many biological functions like transcriptional regulation, cellular trafficking, nuclear compartmentalization, apoptosis, genomic imprinting, and cell cycle (Goyal et al., 2018). Previously published reports demonstrate that lncRNAs exhibit a significant role in various pathophysiological conditions of $\mathrm{CV}$ disorders, including DMCM via targeting miRNA/mRNA or proteins (Zhang et al., 2019).

A recent study performed on diabetic rats showed elevated lncRNAs, including MALAT1, in an STZ model of DMCM. In this study, a knockdown of lncRNA MALAT1 led to an improvement in LV function by reducing cardiomyocyte apoptosis (Zhang et al., 2016). Li X. et al. (2016) recently demonstrated the role of IncRNA H19 in DMCM. They found that H19 levels were downregulated in diabetic patients' myocardium (Li X. et al., 2016). The rescue of H19 expression reduced inflammation, oxidative stress, and apoptosis, leading to an improvement in LV function in STZ-induced SD rats. To tease out a molecular mechanism, Li X. et al. (2016) showed an overexpression of H19, which produces a reduction in VDAC1 expression and apoptosis in HG-treated $(30 \mathrm{mmol} / \mathrm{L})$ cardiomyocytes. This study established a possible novel lncRNA therapeutic approach for treatment of DMCM. An interesting finding by Zheng et al. (2019) reveals that the role of cardiac-specific lncRNA-Crnde (colorectal neoplasia differentially expressed) is negatively associated with cardiac fibrosis in an HFD and low-dose STZ-treated mice. Using the in vitro model system demonstrated that Crnde expression inversely correlates with myofibroblast differentiation, leading to cardiac fibrosis. In corroboration with in vitro findings, in vivo adeno-associated virus-mediated overexpression of Crnde significantly reduced fibrosis. This finding establishes lncRNA therapeutics' potential role against cardiac fibrosis concerning DMCM (Zheng et al., 2019).

Recent findings by Yang et al. (2018) explore the role of ncRNA-Kcnq1ot1 in cardiac pyroptosis in DMCM. This study found elevated levels of Kcnq1ot1 in cardiomyocytes treated with $\mathrm{HG}(50 \mathrm{mmol} / \mathrm{L})$ and in cardiac tissue obtained from STZ-induced diabetic mice. Significantly, lncRNA-Kcnq1ot1 knockdown lowered cardiomyocyte and cardiac cell death and improved cardiac function in vivo. These findings suggest that Kcnq1ot1 could be a potential therapeutic target in DMCM (Yang et al., 2018). Another recent discovery by Qi et al. (2020) revealed that HG-treated cardiomyocytes increased lncRNA-MIAT expression leading to induction of pro-inflammatory cytokine interleukin-17 (IL-17). IL-17 production further promotes inflammation in the heart and subsequently leads to cardiac fibrosis (Qi et al., 2020). A recent report showed lncRNA-Gas5 involvement in apoptosis post hyperglycemia in DMCM neonatal cardiomyocytes (Su et al., 2020). Su et al. (2020) reported that the expression of lncRNA-Gas5 increased significantly in a timedependent manner in HG-treated newly born cardiomyocytes, which subsequently leads to apoptosis. Su et al. (2020) found the rescue of apoptosis when they inhibited the lncRNA-Gas5. Gao et al. (2019) reported the role of the HOX transcript antisense RNA (HOTAIR) lncRNA in DMCM, demonstrating that the overexpression of HOTAIR in cardiomyocytes of STZ-treated mice attenuated the cardiomyocyte death and improved oxidative stress, inflammation, and cardiac function, further investigating the role that HOTAIR plays in in vitro hyperglycemic treated H9c2 cells and finding increased apoptosis, inflammation, and oxidative injury.

Other studies have shown an essential role of lncRNAs. LIPCAR is positively associated with grade I diastolic dysfunction (de Gonzalo-Calvo et al., 2016). SENCAR and MIAT were related to cardiac remodeling observed via LV mass to LV end-diastolic volume ratio. This study highlights the role of lncRNAs as potential predictors of diastolic function in diabetic patients (de Gonzalo-Calvo et al., 2016).

\section{Circular RNAs as Novel Therapeutic Targets for Diabetic Cardiomyopathy}

Circular RNAs were discovered by Sanger et al. (1976) and are "covalently closed single-stranded circular RNA molecules." These classes of RNAs are highly abundant in eukaryotes, and many of them are evolutionary conserved. In respect of other forms of spliced linear RNA, circRNAs are formed by the joining of downstream $5^{\prime}$ splice site to an upstream $3^{\prime}$ splice site, making them covalently circularized RNA loops (Gong et al., 2019). They are derived from exons or introns or a combination of exon/intron or lariats of size ranging 100 nucleotides to $4 \mathrm{~kb}$ (Lasda and Parker, 2014). Due to their unique structure, circRNAs are naturally insusceptible to ribonuclease R (RNase R), which results in their increased half-life (Kishore et al., 2020). These abilities make circRNAs potent biomarkers for various diseases, including heart diseases and diabetes. We have recently demonstrated that circFndc3b expression rescue promoted cardiac repair and improved cardiac function regulating the FUS/VEGF-A axis (Garikipati et al., 2019). A recent report demonstrated a correlation between circRNA (HsacircRNA11783-2) expression, coronary artery disease, and T2DM (Li et al., 2017). Using a db/db mouse subjected to Ang-II stress, Tang et al. (2017) identified upregulation of circRNA_00203, further displaying that overexpression of circRNAs_00203 enhanced fibrosis-related genes Colla2 and CTGF via miR-26b$5 \mathrm{p}$ sponging in isolated cardiac fibroblasts. These studies point out the importance of circRNAs in diabetes-induced cardiac fibrosis (Tang et al., 2017). Yang et al. (2019) recently showed increased hsa_circ_0076631 levels in diabetic patients and cardiomyocytes under hyperglycemic stress. In vitro knockdown 
of hsa_circ_0076631 in cardiomyocytes abolished HG-induced apoptosis via miR-214-3p sponging and inhibiting caspase-1 expression. These results highlight the role of hsa_circ_0076631 regulating pyroptosis in diabetic cardiomyocytes. Given the increasing knowledge on the association of circRNAs in DMCM, there is enormous potential for further exploration of additional mechanisms and novel therapeutic targets.

\section{CONCLUSION AND FUTURE DIRECTIONS}

We summarize that ncRNAs play an important role in DMCM. Of the ncRNAs focused in this review, miRNAs are the most studied in the context of CVD. Tremendous progress on miRNAbased therapeutics led them to clinical trials. In a phase 1 clinical trial, CDR1321 (a novel synthetic miR-92a inhibitor) was used to treat $\mathrm{HF}^{1}$ (unique identifier: NCT04045405). A phase 1 clinical trial has recently been initiated using RG-102 (miR-21 inhibitor) to treat kidney fibrosis (see text footnote 1; unique identifier: NCT03373786). This is encouraging; however, significant hurdles with miRNA therapeutics include delivering miRNA inhibitors to specific organs/cells and associated off-target effects.

Circulating ncRNAs including miRNA (miR-320), lncRNA (lncRNA-LIPCAR, SENCAR, and MIAT), and circRNA (HsacircRNA11783-2 and hsa_circ_0076631) were shown to have diagnostic and prognostic values (de Gonzalo-Calvo et al., 2016; Li et al., 2017, 2019; Yang et al., 2019). Given that the studies performed were in a small patient cohort, future studies should focus on a larger number of patients, multi-centric trials, racial backgrounds, and different time points after diabetes.

While the field of long ncRNAs (lncRNA and circRNAs) is emerging in the context of DMCM, for a comprehensive understanding of lncRNAs in DMCM, the following issues

${ }^{1}$ https://www.clinicaltrials.gov

\section{REFERENCES}

Abarca-Gómez, L., Abdeen, Z. A., Hamid, Z. A., Abu-Rmeileh, N. M., Acosta-Cazares, B., Acuin, C., et al. (2017). Worldwide trends in body-mass index, underweight, overweight, and obesity from 1975 to 2016: a pooled analysis of 2416 population-based measurement studies in 128.9 million children, adolescents, and adults. Lancet 390, 2627-2642.

Advance Collaborative Group, Patel, A., MacMahon, S., Chalmers, J., Neal, B., Billot, L., et al. (2008). Intensive blood glucose control and vascular outcomes in patients with type 2 diabetes. N. Engl. J. Med. 358, 2560-2572. doi: 10.1056/ nejmoa0802987

Aepfelbacher, F. C., Yeon, S. B., Weinrauch, L. A., D'elia, J., and Burger, A. J. (2004). Improved glycemic control induces regression of left ventricular mass in patients with type 1 diabetes mellitus. Int. J. Cardiol. 94, 47-51. doi: 10.1016/ j.ijcard.2003.04.012

Aguilar, D., Bozkurt, B., Ramasubbu, K., and Deswal, A. (2009). Relationship of hemoglobin A1C and mortality in heart failure patients with diabetes. J. Am. Coll. Cardiol. 54, 422-428. doi: 10.1016/j.jacc.2009.04.049

Alex, L., Russo, I., Holoborodko, V., and Frangogiannis, N. G. (2018). Integrative cardiovascular physiology and pathophysiology: characterization of a mouse model of obesity-related fibrotic cardiomyopathy that recapitulates features of need to be addressed: (a) robust computational techniques for their identification and downstream targets should be standardized, (b) novel regulatory mechanisms need to be uncovered (apart from their miRNA/RNA binding protein interaction), (c) it should be investigated if lncRNA translation products proteins/peptides are functional, and (d) genetic models of lncRNA should be established.

Thus, identification, characterization, and mechanisms of ncRNAs (especially lncRNA and circRNAs), which play a regulatory role in the network of interactions governing DMCM, are fundamental pieces of the puzzle that need to be solved to allow better treatment and prevention of DMCM.

\section{AUTHOR CONTRIBUTIONS}

AR, RG, and VNSG conceived the study. AR, RG, and DR collected the material and wrote the manuscript. MK and VNSG provided critical feedback and helped to shape the manuscript. $\mathrm{BL}$ contributed towards manuscript revision and rewriting few sections during the revision of manuscript. All authors contributed to the article and approved the submitted version.

\section{FUNDING}

This work was partially supported by the American Heart Association Career Development Award 18CDA34110277 and startup funds from the Ohio State University to VNSG. This work was also supported by the National Heart Lung and Blood Institute HL136232 to MK.

\section{ACKNOWLEDGMENTS}

We apologize to those whose original work could not be cited owing to space limitations.

human heart failure with preserved ejection fraction. Am. J. Physiol. Heart Circ. Physiol. 315:H934.

Anjana, R. M., Deepa, M., Pradeepa, R., Mahanta, J., Narain, K., Das, H. K., et al. (2017). Prevalence of diabetes and prediabetes in 15 states of India: results from the ICMR-INDIAB population-based cross-sectional study. Lancet Diabetes Endocrinol. 5, 585-596.

Banerjee, S. K., Mcgaffin, K. R., Pastor-Soler, N. M., and Ahmad, F. (2009). SGLT1 is a novel cardiac glucose transporter that is perturbed in disease states. Cardiovasc. Res. 84, 111-118. doi: 10.1093/cvr/cvp190

Borghetti, G., Von Lewinski, D., Eaton, D. M., Sourij, H., Houser, S. R., and Wallner, M. (2018). Diabetic cardiomyopathy: current and future therapies. Beyond glycemic control. Front. Physiol. 9:1514. doi: 10.3389/fphys.2018.01514

Cai, Q., Li, B., Yu, F., Lu, W., Zhang, Z., Yin, M., et al. (2013). Investigation of the protective effects of phlorizin on diabetic cardiomyopathy in $\mathrm{db} / \mathrm{db}$ mice by quantitative proteomics. J. Diabetes Res. 2013:263845.

Castagno, D., Baird-Gunning, J., Jhund, P. S., Biondi-Zoccai, G., Macdonald, M. R., Petrie, M. C., et al. (2011). Intensive glycemic control has no impact on the risk of heart failure in type 2 diabetic patients: evidence from a 37,229 patient meta-analysis. Am. Heart. J. 162, 938.e2-948.e2.

Centers for Disease Control and Prevention (2020). National Diabetes Statistics Report, 2020. Atlanta, GA: Centers for Disease Control and Prevention, US Department of Health and Human Services. 
Chen, S., Puthanveetil, P., Feng, B., Matkovich, S. J., Dorn, G. W., and Chakrabarti, S. (2014). Cardiac miR-133a overexpression prevents early cardiac fibrosis in diabetes. J. Cell Mol. Med. 18, 415-421. doi: 10.1111/jcmm.12218

Cho, N., Shaw, J., Karuranga, S., Huang, Y., Da Rocha Fernandes, J., Ohlrogge, A., et al. (2018). IDF Diabetes Atlas: global estimates of diabetes prevalence for 2017 and projections for 2045. Diabetes. Res. Clin. Pract. 138, 271-281. doi: 10.1016/j.diabres.2018.02.023

Control, D., and Trial, C. (2016). Intensive diabetes treatment and cardiovascular outcomes in type 1 diabetes: the DCCT/EDIC study 30-year follow-up. Diabetes Care 39, 686-693. doi: 10.2337/dc15-1990

Copier, C. U., León, L., Fernández, M., Contador, D., and Calligaris, S. D. (2017). Circulating miR-19b and miR-181b are potential biomarkers for diabetic cardiomyopathy. Sci. Rep. 7, 1-11.

Coskun, T., Sloop, K. W., Loghin, C., Alsina-Fernandez, J., Urva, S., Bokvist, K. B., et al. (2018). LY3298176, a novel dual GIP and GLP-1 receptor agonist for the treatment of type 2 diabetes mellitus: from discovery to clinical proof of concept. Mol. Metab. 18, 3-14. doi: 10.1016/j.molmet.2018.09.009

de Gonzalo-Calvo, D., Kenneweg, F., Bang, C., Toro, R., Van Der Meer, R., Rijzewijk, L., et al. (2016). Circulating long-non coding RNAs as biomarkers of left ventricular diastolic function and remodelling in patients with wellcontrolled type 2 diabetes. Sci. Rep. 6, 1-12.

Delorme, S., and Chiasson, J.-L. (2005). Acarbose in the prevention of cardiovascular disease in subjects with impaired glucose tolerance and type 2 diabetes mellitus. Curr. Opin. Pharmacol. 5, 184-189. doi: 10.1016/j.coph.2004. 11.005

Devereux, R. B., Roman, M. J., Paranicas, M., O’grady, M. J., Lee, E. T., Welty, T. K., et al. (2000). Impact of diabetes on cardiac structure and function: the strong heart study. Circulation 101, 2271-2276. doi: 10.1161/01.cir.101.19.2271

DiMeglio, L. A., Evans-Molina, C., and Oram, R. A. (2018). Type 1 diabetes. Lancet 391, 2449-2462.

Dormandy, J. A., Charbonnel, B., Eckland, D. J., Erdmann, E., Massi-Benedetti, M., Moules, I. K., et al. (2005). Secondary prevention of macrovascular events in patients with type 2 diabetes in the PROactive Study (PROspective pioglitAzone Clinical Trial In macroVascular Events): a randomised controlled trial. Lancet 366, 1279-1289. doi: 10.1016/s0140-6736(05)67528-9

Dunlay, S. M., Givertz, M. M., Aguilar, D., Allen, L. A., Chan, M., Desai, A. S., et al. (2019). Type 2 diabetes mellitus and heart failure: a scientific statement from the american heart association and the heart failure society of america: this statement does not represent an update of the 2017 ACC/AHA/HFSA heart failure guideline update. Circulation 140, e294-e324.

Esteller, M. (2011). Non-coding RNAs in human disease. Nat. Rev. Genet. 12, 861-874.

Eurich, D. T., Weir, D. L., Majumdar, S. R., Tsuyuki, R. T., Johnson, J. A., Tjosvold, L., et al. (2013). Comparative safety and effectiveness of metformin in patients with diabetes mellitus and heart failure: systematic review of observational studies involving 34000 patients. Circ. Heart Fail. 6, 395-402. doi: 10.1161/ circheartfailure.112.000162

Factor, S. M., Bhan, R., Minase, T., Wolinsky, H., and Sonnenblick, E. H. (1981). Hypertensive-diabetic cardiomyopathy in the rat: an experimental model of human disease. Am. J. Pathol. 102:219.

Fang, Z., Du, R., Edwards, A., Flemington, E. K., and Zhang, K. (2013). The sequence structures of human microRNA molecules and their implications. PLoS One 8:e54215. doi: 10.1371/journal.pone.0054215

Fein, F. S., Malhotra, A., Miller-Green, B., Scheuer, J., and Sonnenblick, E. H. (1984). Diabetic cardiomyopathy in rats: mechanical and biochemical response to different insulin doses. Am. J. Physiol. Heart Circ. Physiol. 247, H817H823.

Feng, B., Cao, Y., Chen, S., Chu, X., Chu, Y., and Chakrabarti, S. (2016). miR-200b mediates endothelial-to-mesenchymal transition in diabetic cardiomyopathy. Diabetes Metab. Res. Rev. 65, 768-779. doi: 10.2337/db15-1033

Feng, B., Chen, S., George, B., Feng, Q., and Chakrabarti, S. (2010). miR133a regulates cardiomyocyte hypertrophy in diabetes. Diabetes Metab. Res. Rev. 26, 40-49. doi: 10.1002/dmrr.1054

Fletcher, B., Gulanick, M., and Lamendola, C. (2002). Risk factors for type 2 diabetes mellitus. J. Cardiovasc. Nurs. 16, 17-23. doi: 10.1002/9781118387658. ch2

Frias, J. P., Nauck, M. A., Van, J., Kutner, M. E., Cui, X., Benson, C., et al. (2018). Efficacy and safety of LY3298176, a novel dual GIP and GLP-1 receptor agonist, in patients with type 2 diabetes: a randomised, placebo-controlled and active comparator-controlled phase 2 trial. Lancet 392, 2180-2193. doi: 10.1016/ s0140-6736(18)32260-8

Ganguly, P. K., Pierce, G. N., Dhalla, K., and Dhalla, N. S. (1983). Defective sarcoplasmic reticular calcium transport in diabetic cardiomyopathy. Am. J. Physiol. Endocrinol. Metab. 244, E528-E535.

Gao, L., Wang, X., Guo, S., Xiao, L., Liang, C., Wang, Z., et al. (2019). LncRNA HOTAIR functions as a competing endogenous RNA to upregulate SIRT1 by sponging miR-34a in diabetic cardiomyopathy. J. Cell. Physiol. 234, 4944-4958. doi: $10.1002 /$ jcp. 27296

Garber, A. J., Abrahamson, M. J., Barzilay, J. I., Blonde, L., Bloomgarden, Z. T., Bush, M. A., et al. (2018). Consensus statement by the American Association of Clinical Endocrinologists and American College of Endocrinology on the comprehensive type 2 diabetes management algorithm-2018 executive summary. Endocr. Pract. 24, 91-120. doi: 10.4158/cs-20170153

Garikipati, V. N. S., Verma, S. K., Cheng, Z., Liang, D., Truongcao, M. M., Cimini, M., et al. (2019). Circular RNA CircFndc3b modulates cardiac repair after myocardial infarction via FUS/VEGF-A axis. Nat. Commun. 10, 1-14.

Gélinas, R., Mailleux, F., Dontaine, J., Bultot, L., Demeulder, B., Ginion, A., et al. (2018). AMPK activation counteracts cardiac hypertrophy by reducing O-GlcNAcylation. Nat. Commun. 9, 1-17.

Gerstein, H. C., Colhoun, H. M., Dagenais, G. R., Diaz, R., Lakshmanan, M., Pais, P., et al. (2019). Dulaglutide and cardiovascular outcomes in type 2 diabetes (REWIND): a double-blind, randomised placebo-controlled trial. Lancet 394, $121-130$.

Gong, X., Wu, G., and Zeng, C. (2019). Role of circular RNAs in cardiovascular diseases. Exp. Biol. Med. 244, 73-82. doi: 10.1177/1535370218822988

Goyal, N., Kesharwani, D., and Datta, M. (2018). Lnc-ing non-coding RNAs with metabolism and diabetes: roles of lncRNAs. Cell. Mol. Life Sci. 75, 1827-1837. doi: 10.1007/s00018-018-2760-9

Grandi, A. M., Imperiale, D., Santillo, R., Barlocco, E., Bertolini, A., Guasti, L., et al. (2002). Aldosterone antagonist improves diastolic function in essential hypertension. Hypertension 40, 647-652. doi: 10.1161/01.hyp.0000036399. 80194.d8

Grandi, A. M., Piantanida, E., Franzetti, I., Bernasconi, M., Maresca, A., Marnini, P., et al. (2006). Effect of glycemic control on left ventricular diastolic function in type 1 diabetes mellitus. Am. J. Cardiol. 97, 71-76. doi: 10.1016/j.amjcard. 2005.07.110

Green, J. B., Bethel, M. A., Armstrong, P. W., Buse, J. B., Engel, S. S., Garg, J., et al. (2015). Effect of sitagliptin on cardiovascular outcomes in type 2 diabetes. New Engl. J. Med. 373, 232-242.

Group, U. P. D. S. (1998). Intensive blood-glucose control with sulphonylureas or insulin compared with conventional treatment and risk of complications in patients with type 2 diabetes (UKPDS 33). Lancet 352, 837-853. doi: 10.1016/ s0140-6736(98)07019-6

Guo, R., and Nair, S. (2017). Role of microRNA in diabetic cardiomyopathy: from mechanism to intervention. Biochim. Biophys Acta Mol. Basis Dis. 1863, 2070-2077. doi: 10.1016/j.bbadis.2017.03.013

Ha, M., and Kim, V. N. (2014). Regulation of microRNA biogenesis. Nat. Rev. Mol. Cell Biol. 15, 509-524.

Han, Y., Xie, H., Liu, Y., Gao, P., Yang, X., and Shen, Z. (2019). Effect of metformin on all-cause and cardiovascular mortality in patients with coronary artery diseases: a systematic review and an updated meta-analysis. Cardiovasc. Diabetol. 18:96.

Hattori, Y., Suzuki, K., Hattori, S., and Kasai, K. (2006). Metformin inhibits cytokine-induced nuclear factor $\kappa \mathrm{B}$ activation via AMP-activated protein kinase activation in vascular endothelial cells. Hypertension 47, 1183-1188. doi: 10. 1161/01.hyp.0000221429.94591.72

Held, C., Gerstein, H., Yusuf, S., Zhao, F., Hilbrich, L., Anderson, C., et al. (2007). Glucose levels predict hospitalization for congestive heart failure in patients at high cardiovascular risk. Circulation 115, 1371-1375. doi: 10.1161/ circulationaha.106.661405

Hernandez, A. F., Green, J. B., Janmohamed, S., D’agostino, R. B. Sr., Granger, C. B., Jones, N. P., et al. (2018). Albiglutide and cardiovascular outcomes in patients with type 2 diabetes and cardiovascular disease (Harmony Outcomes): a double-blind, randomised placebo-controlled trial. Lancet 392, 1519-1529. 
Holman, R. R., Bethel, M. A., Mentz, R. J., Thompson, V. P., Lokhnygina, Y., Buse, J. B., et al. (2017a). Effects of once-weekly exenatide on cardiovascular outcomes in type 2 diabetes. New Engl. J. Med. 377, 1228-1239.

Holman, R. R., Coleman, R. L., Chan, J. C., Chiasson, J.-L., Feng, H., Ge, J., et al. (2017b). Effects of acarbose on cardiovascular and diabetes outcomes in patients with coronary heart disease and impaired glucose tolerance (ACE): a randomised, double-blind, placebo-controlled trial. Lancet Diabetes Endocrinol. $5,877-886$.

Holst, J. J., and Rosenkilde, M. M. (2020). GIP as a therapeutic target in diabetes and obesity: insight from incretin co-agonists. J. Clin. Endocrinol. Metab. 105, e2710-e2716.

Horie, T., Ono, K., Nishi, H., Iwanaga, Y., Nagao, K., Kinoshita, M., et al. (2009). MicroRNA-133 regulates the expression of GLUT4 by targeting KLF15 and is involved in metabolic control in cardiac myocytes. Biochem. Biophys. Res. Commun. 389, 315-320. doi: 10.1016/j.bbrc.2009.08.136

Husain, M., Birkenfeld, A. L., Donsmark, M., Dungan, K., Eliaschewitz, F. G., Franco, D. R., et al. (2019). Oral semaglutide and cardiovascular outcomes in patients with type 2 diabetes. New Engl. J. Med. 381, 841-851.

Insulin, B. (2012). Cardiovascular and other outcomes in dysglycemia. N. Engl. J. Med. 367, 319-328. doi: 10.1056/nejmoa1203858

Isoda, K., Young, J. L., Zirlik, A., Macfarlane, L. A., Tsuboi, N., Gerdes, N., et al. (2006). Metformin inhibits proinflammatory responses and nuclear factor- $\kappa \mathrm{B}$ in human vascular wall cells. Arterioscler. Thromb. Vasc. Biol. 26, 611-617. doi: 10.1161/01.atv.0000201938.78044.75

Jackson, C., McGrath, G. M., Tahiliani, A. G., Vadlamudi, R. V., and McNeill, J. H. (1985). A functional and ultrastructural analysis of experimental diabetic rat myocardium. Manifestation of a cardiomyopathy. Diabetes 34, 876-883. doi: $10.2337 /$ diabetes.34.9.876

Jiang, J., Ahn, J., Huang, W.-Y., and Hayes, R. B. (2013). Association of obesity with cardiovascular disease mortality in the PLCO trial. Prev. Med. 57, 60-64. doi: 10.1016/j.ypmed.2013.04.014

Joladarashi, D., Garikipati, V. N. S., Thandavarayan, R. A., Verma, S. K., Mackie, A. R., Khan, M., et al. (2015). Enhanced cardiac regenerative ability of stem cells after ischemia-reperfusion injury: role of human CD34+ cells deficient in microRNA-377. J. Am. Coll. Cardiol. 66, 2214-2226. doi: 10.1016/j.jacc.2015. 09.009

Jorsal, A., Kistorp, C., Holmager, P., Tougaard, R. S., Nielsen, R., Hänselmann, A., et al. (2017). Effect of liraglutide, a glucagon-like peptide-1 analogue, on left ventricular function in stable chronic heart failure patients with and without diabetes (LIVE) - a multicentre, double-blind, randomised, placebo-controlled trial. Eur. J. Heart Fail. 19, 69-77. doi: 10.1002/ ejhf.657

Kenchaiah, S., Evans, J. C., Levy, D., Wilson, P. W., Benjamin, E. J., Larson, M. G., et al. (2002). Obesity and the risk of heart failure. N. Engl. J. Med. 347, 305-313.

Kernan, W. N., Viscoli, C. M., Furie, K. L., Young, L. H., Inzucchi, S. E., Gorman, M., et al. (2016). Pioglitazone after ischemic stroke or transient ischemic attack. N. Engl. J. Med. 374, 1321-1331.

Kishore, R., Garikipati, V. N., and Gonzalez, C. (2020). Role of circular RNAs in cardiovascular disease. J. Cardiovasc. Pharmacol. 76, 128-137.

Kopp, F., and Mendell, J. T. (2018). Functional classification and experimental dissection of long noncoding RNAs. Cell 172, 393-407. doi: 10.1016/j.cell.2018. 01.011

Kuwabara, Y., Horie, T., Baba, O., Watanabe, S., Nishiga, M., Usami, S., et al. (2015). MicroRNA-451 exacerbates lipotoxicity in cardiac myocytes and highfat diet-induced cardiac hypertrophy in mice through suppression of the LKB1/AMPK pathway. Circ. Res. 116, 279-288. doi: 10.1161/circresaha.116. 304707

Lasda, E., and Parker, R. (2014). Circular RNAs: diversity of form and function. RNA 20, 1829-1842. doi: 10.1261/rna.047126.114

Lear, S. A., Humphries, K. H., Kohli, S., Chockalingam, A., Frohlich, J. J., and Birmingham, C. L. (2007). Visceral adipose tissue accumulation differs according to ethnic background: results of the multicultural community health assessment trial (M-CHAT). Am. J. Clin. Nutr. 86, 353-359. doi: 10.1093/ajcn/ 86.2.353

Lee, R. C., Feinbaum, R. L., and Ambros, V. (1993). The C. elegans heterochronic gene lin-4 encodes small RNAs with antisense complementarity to lin-14. Cell 75, 843-854. doi: 10.1016/0092-8674(93)90529-y
Lew, J. K.-S., Pearson, J. T., Saw, E., Tsuchimochi, H., Wei, M. Y., Ghosh, N., et al. (2020). Exercise regulates microRNAs to preserve coronary and cardiac function in the diabetic heart. Circ. Res. 127, 1401-1403.

Lewis, E. J., and Lewis, J. B. (2004). ACE inhibitors versus angiotensin receptor blockers in diabetic nephropathy: is there a winner? J. Am. Soc. Nephrol. 15, 1358-1360.

Leyden, E. V. (1881). Asthma and diabetes mellitus. Z. Klin Med. 3, 358-364.

Li, H., Fan, J., Zhao, Y., Zhang, X., Dai, B., Zhan, J., et al. (2019). Nuclear miR320 mediates diabetes-induced cardiac dysfunction by activating transcription of fatty acid metabolic genes to cause lipotoxicity in the heart. Circ. Res. 125, 1106-1120. doi: 10.1161/circresaha.119.314898

Li, J., Jin, W., Qin, Y., Zhao, W., Chang, C., and Xu, C. (2016). Expression profile and function analysis of LncRNAs during priming phase of rat liver regeneration. PLoS One 11:e0156128. doi: 10.1371/journal.pone.015 6128

Li, X., Wang, H., Yao, B., Xu, W., Chen, J., and Zhou, X. (2016). IncRNA H19/miR675 axis regulates cardiomyocyte apoptosis by targeting VDAC1 in diabetic cardiomyopathy. Sci. Rep. 6:36340.

Li, X., Zhao, Z., Jian, D., Li, W., Tang, H., and Li, M. (2017). Hsa-circRNA11783-2 in peripheral blood is correlated with coronary artery disease and type 2 diabetes mellitus. Diabetes Vasc. Dis. Res. 14, 510-515. doi: 10.1177/1479164117722714

Liang, Y., Ridzon, D., Wong, L., and Chen, C. (2007). Characterization of microRNA expression profiles in normal human tissues. BMC Genomics 8:166. doi: 10.1186/1471-2164-8-166

Liu, S., Li, W., Xu, M., Huang, H., Wang, J., and Chen, X. (2014). Micro-RNA 21 targets dual specific phosphatase 8 to promote collagen synthesis in high glucose-treated primary cardiac fibroblasts. Can. J. Cardiol. 30, 1689-1699. doi: 10.1016/j.cjca.2014.07.747

Lorenzo-Almoros, A., Tunon, J., Orejas, M., Cortés, M., Egido, J., and Lorenzo, Ó (2017). Diagnostic approaches for diabetic cardiomyopathy. Cardiovasc. Diabetol. 16, 1-14.

Lu, T. X., and Rothenberg, M. E. (2018). MicroRNA. J. Allergy Clin. Immunol. 141, 1202-1207.

Mahajan, R., Stokes, M., Elliott, A., Munawar, D. A., Khokhar, K. B., Thiyagarajah, A., et al. (2020). Complex interaction of obesity, intentional weight loss and heart failure: a systematic review and meta-analysis. Heart 106, 58-68. doi: 10.1136/heartjnl-2019-314770

Malhotra, A., Penpargkul, S., Fein, F. S., Sonnenblick, E. H., and Scheuer, J. (1981). The effect of streptozotocin-induced diabetes in rats on cardiac contractile proteins. Circ. Res. 49, 1243-1250. doi: 10.1161/01.res.49.6.1243

Margulies, K. B., Hernandez, A. F., Redfield, M. M., Givertz, M. M., Oliveira, G. H., Cole, R., et al. (2016). Effects of liraglutide on clinical stability among patients with advanced heart failure and reduced ejection fraction: a randomized clinical trial. JAMA 316, 500-508. doi: 10.1001/jama.2016.10260

Marso, S. P., Bain, S. C., Consoli, A., Eliaschewitz, F. G., Jódar, E., Leiter, L. A., et al. (2016a). Semaglutide and cardiovascular outcomes in patients with type 2 diabetes. N. Engl. J. Med. 375, 1834-1844.

Marso, S. P., Daniels, G. H., Brown-Frandsen, K., Kristensen, P., Mann, J. F., Nauck, M. A., et al. (2016b). Liraglutide and cardiovascular outcomes in type 2 diabetes. N. Engl. J. Med. 375, 311-322.

Matsushita, K., Blecker, S., Pazin-Filho, A., Bertoni, A., Chang, P. P., Coresh, J., et al. (2010). The association of hemoglobin alc with incident heart failure among people without diabetes: the atherosclerosis risk in communities study. Diabetes Metab. Res. Rev. 59, 2020-2026. doi: 10.2337/db10-0165

McMurray, J. J., Packer, M., Desai, A. S., Gong, J., Lefkowitz, M. P., Rizkala, A. R., et al. (2014). Angiotensin-neprilysin inhibition versus enalapril in heart failure. N. Engl. J. Med. 371, 993-1004.

McMurray, J. J., Solomon, S. D., Inzucchi, S. E., Køber, L., Kosiborod, M. N., Martinez, F. A., et al. (2019). Dapagliflozin in patients with heart failure and reduced ejection fraction. N. Engl. J. Med. 381, 1995-2008.

Must, A., Jacques, P. F., Dallal, G. E., Bajema, C. J., and Dietz, W. H. (1992). Long-term morbidity and mortality of overweight adolescents: a follow-up of the Harvard Growth Study of 1922 to 1935. N. Engl. J. Med. 327, 1350-1355. doi: 10.1056/nejm199211053271904

Nandi, S. S., Zheng, H., Sharma, N. M., Shahshahan, H. R., Patel, K. P., and Mishra, P. K. (2016). Lack of miR-133a decreases contractility of diabetic hearts: a role for novel cross talk between tyrosine aminotransferase and tyrosine hydroxylase. Diabetes 65, 3075-3090. doi: 10.2337/db16-0023 
Neal, B., Perkovic, V., Mahaffey, K. W., De Zeeuw, D., Fulcher, G., Erondu, N., et al. (2017). Canagliflozin and cardiovascular and renal events in type 2 diabetes. N. Engl. J. Med. 377, 644-657.

Ng, M., Fleming, T., Robinson, M., Thomson, B., and Graetz, N. (2014). Global, regional, and national prevalence of overweight and obesity in children and adults during 1980-2013: a systematic analysis for the Global Burden of Disease Study 2013. Lancet 384, 766-781.

Oelze, M., Kröller-Schön, S., Welschof, P., Jansen, T., Hausding, M., Mikhed, Y., et al. (2014). The sodium-glucose co-transporter 2 inhibitor empagliflozin improves diabetes-induced vascular dysfunction in the streptozotocin diabetes rat model by interfering with oxidative stress and glucotoxicity. PLoS One 9:e112394. doi: 10.1371/journal.pone.0112394

Packer, M. (2018). Do DPP-4 inhibitors cause heart failure events by promoting adrenergically mediated cardiotoxicity? Clues from laboratory models and clinical trials. Circ. Res. 122, 928-932. doi: 10.1161/circresaha.118.31 2673

Packer, M., Anker, S. D., Butler, J., Filippatos, G., Pocock, S. J., Carson, P., et al. (2020). Cardiovascular and renal outcomes with empagliflozin in heart failure. N. Engl. J. Med. 383, 1413-1424.

Palazzo, A. F., and Koonin, E. V. (2020). Functional long non-coding RNAs evolve from junk transcripts. Cell 183, 1151-1161. doi: 10.1016/j.cell.2020.09.047

Pfeffer, M. A., Claggett, B., Diaz, R., Dickstein, K., Gerstein, H. C., Køber, L. V., et al. (2015). Lixisenatide in patients with type 2 diabetes and acute coronary syndrome. N. Engl. J. Med. 373, 2247-2257.

Pokharel, Y., Sun, W., Virani, S. S., Nambi, V., Hoogeveen, R. C., Chang, P. P., et al. (2017). Myocardial injury, obesity, and the obesity paradox: the ARIC study. JACC: Heart Fail. 5, 56-63.

Ponikowski, P., Voors, A. A., Anker, S. D., Bueno, H., Cleland, J. G., Coats, A. J., et al. (2016). 2016 ESC Guidelines for the diagnosis and treatment of acute and chronic heart failure: the task force for the diagnosis and treatment of acute and chronic heart failure of the european society of cardiology (ESC) developed with the special contribution of the heart failure association (HFA) of the ESC. Eur. Heart J. 37, 2129-2200.

Powell, D. R., Zambrowicz, B., Morrow, L., Beysen, C., Hompesch, M., Turner, S., et al. (2020). Sotagliflozin decreases postprandial glucose and insulin concentrations by delaying intestinal glucose absorption. J. Clin. Endocrinol. Metab. 105, e1235-e1249.

Qi, Y., Wu, H., Mai, C., Lin, H., Shen, J., Zhang, X., et al. (2020). LncRNAMIAT-mediated miR-214-3p silencing is responsible for IL-17 production and cardiac fibrosis in diabetic cardiomyopathy. Front. Cell Dev. Biol. 8:243. doi: $10.3389 /$ fcell.2020.00243

Ramratnam, M., Sharma, R. K., D'auria, S., Lee, S. J., Wang, D., Huang, X. Y. N., et al. (2014). Transgenic knockdown of cardiac sodium/glucose cotransporter 1 (SGLT 1) attenuates PRKAG 2 cardiomyopathy, whereas transgenic overexpression of cardiac SGLT 1 causes pathologic hypertrophy and dysfunction in mice. J. Am. Heart Assoc. 3:e000899.

Reaven, P. D., Emanuele, N. V., Wiitala, W. L., Bahn, G. D., Reda, D. J., Mccarren, M., et al. (2019). Intensive glucose control in patients with type 2 diabetes-15year follow-up. N. Engl. J. Med. 380, 2215-2224. doi: 10.1056/nejmoa1806802

Rubler, S., Dlugash, J., Yuceoglu, Y. Z., Kumral, T., Branwood, A. W., and Grishman, A. (1972). New type of cardiomyopathy associated with diabetic glomerulosclerosis. Am. J. Cardiol. 30, 595-602. doi: 10.1016/0002-9149(72) 90595-4

Salim, H. M., Fukuda, D., Yagi, S., Soeki, T., Shimabukuro, M., and Sata, M. (2016). Glycemic control with ipragliflozin, a novel selective SGLT2 inhibitor, ameliorated endothelial dysfunction in streptozotocin-induced diabetic mouse. Front. Cardiovasc. Med. 3:43. doi: 10.3389/fcvm.2016.00043

Sanger, H. L., Klotz, G., Riesner, D., Gross, H. J., and Kleinschmidt, A. K. (1976). Viroids are single-stranded covalently closed circular RNA molecules existing as highly base-paired rod-like structures. Proc. Natl. Acad. Sci. U S A. 73, 3852-3856. doi: 10.1073/pnas.73.11.3852

Schaumberg, D. A., Glynn, R. J., Jenkins, A. J., Lyons, T. J., Rifai, N., Manson, J. E., et al. (2005). Effect of intensive glycemic control on levels of markers of inflammation in type 1 diabetes mellitus in the diabetes control and complications trial. Circulation 111, 2446-2453. doi: 10.1161/01.cir. $0000165064.31505 .3 \mathrm{~b}$

Shiraki, A., Oyama, J.-I., Nishikido, T., and Node, K. (2019). GLP-1 analog liraglutide-induced cardiac dysfunction due to energetic starvation in heart failure with non-diabetic dilated cardiomyopathy. Cardiovasc. Diabetol. 18:164.

Shishehbor, M. H., Hoogwerf, B. J., Schoenhagen, P., Marso, S. P., Sun, J. P., Li, J., et al. (2003). Relation of hemoglobin Alc to left ventricular relaxation in patients with type 1 diabetes mellitus and without overt heart disease. Am. J. Cardiol. 91, 1514-1517. doi: 10.1016/s0002-9149(03)00414-4

Singh, G. B., Raut, S. K., Khanna, S., Kumar, A., Sharma, S., Prasad, R., et al. (2017). MicroRNA-200c modulates DUSP-1 expression in diabetes-induced cardiac hypertrophy. Mol. Cell. Biochem. 424, 1-11. doi: 10.1007/s11010-016-2838-3

Slater, R. E., Strom, J. G., Methawasin, M., Liss, M., Gotthardt, M., Sweitzer, N., et al. (2019). Metformin improves diastolic function in an HFpEF-like mouse model by increasing titin compliance. J. Gen. Physiol. 151, 42-52. doi: 10.1085/ jgp.201812259

Solomon, S. D., McMurray, J. J., Anand, I. S., Ge, J., Lam, C. S., Maggioni, A. P., et al. (2019). Angiotensin-neprilysin inhibition in heart failure with preserved ejection fraction. N. Engl. J. Med. 381, 1609-1620.

Su, D., Ju, Y., Han, W., Yang, Y., Wang, F., Wang, T., et al. (2020). Tcf3-activated lncRNA Gas5 regulates newborn mouse cardiomyocyte apoptosis in diabetic cardiomyopathy. J. Cell. Biochem. 121, 4337-4346. doi: 10.1002/jcb.29630

Swedberg, K., Komajda, M., Böhm, M., Borer, J. S., Ford, I., Dubost-Brama, A., et al. (2010). Ivabradine and outcomes in chronic heart failure (SHIFT): a randomised placebo-controlled study. Lancet 376, 875-885. doi: 10.1016/ s0140-6736(10)61198-1

Tan, Y., Zhang, Z., Zheng, C., Wintergerst, K. A., Keller, B. B., and Cai, L. (2020). Mechanisms of diabetic cardiomyopathy and potential therapeutic strategies: preclinical and clinical evidence. Nat. Rev. Cardiol. 17, 585-607. doi: 10.1038/ s41569-020-0339-2

Tang, C.-M., Zhang, M., Huang, L., Hu, Z.-Q., Zhu, J.-N., Xiao, Z., et al. (2017). CircRNA_000203 enhances the expression of fibrosis-associated genes by derepressing targets of miR-26b-5p, Col1a2 and CTGF, in cardiac fibroblasts. Sci. Rep. 7, 1-9.

Tang, Q., Len, Q., Liu, Z., and Wang, W. (2018). Overexpression of miR22 attenuates oxidative stress injury in diabetic cardiomyopathy via Sirt 1. Cardiovasc. Ther. 36:e12318. doi: 10.1111/1755-5922.12318

Tao, L., Huang, X., Xu, M., Yang, L., and Hua, F. (2020). MiR-144 protects the heart from hyperglycemia-induced injury by regulating mitochondrial biogenesis and cardiomyocyte apoptosis. FASEB J. 34, 2173-2197. doi: 10.1096/fj.201901838r

Tariq, A., Hao, Q., Sun, Q., Singh, D. K., Jadaliha, M., Zhang, Y., et al. (2020). LncRNA-mediated regulation of SOX9 expression in basal subtype breast cancer cells. RNA 26, 175-185. doi: 10.1261/rna.073254.119

Tsao-Wu, M., Williams, R. J., Hendy, H. M., and Novick, M. B. (2019). Associations between obesity severity and medical comorbidities for children with obesity in low intensity hospital intervention. Obes. Res. Clin. Pract. 13, 555-560. doi: 10.1016/j.orcp.2019.11.001

Tseng, C. H. (2019). Metformin use is associated with a lower risk of hospitalization for heart failure in patients with type 2 diabetes mellitus: a retrospective cohort analysis. J. Am. Heart Assoc. 8:e011640.

Ulitsky, I., and Bartel, D. P. (2013). lincRNAs: genomics, evolution, and mechanisms. Cell 154, 26-46. doi: 10.1016/j.cell.2013.06.020

Uthman, L., Baartscheer, A., Bleijlevens, B., Schumacher, C. A., Fiolet, J. W., Koeman, A., et al. (2018). Class effects of SGLT2 inhibitors in mouse cardiomyocytes and hearts: inhibition of $\mathrm{Na}+\mathrm{H}+$ exchanger, lowering of cytosolic Na+ and vasodilation. Diabetologia 61, 722-726. doi: 10.1007/s00125017-4509-7

Van Rooij, E., Sutherland, L. B., Thatcher, J. E., Dimaio, J. M., Naseem, R. H., Marshall, W. S., et al. (2008). Dysregulation of microRNAs after myocardial infarction reveals a role of miR-29 in cardiac fibrosis. Proc. Natl. Acad. Sci. U.S.A. 105, 13027-13032. doi: 10.1073/pnas.0805038105

Verma, S. K., Garikipati, V. N., Krishnamurthy, P., Schumacher, S. M., Grisanti, L. A., Cimini, M., et al. (2017a). Interleukin-10 inhibits bone marrow fibroblast progenitor cell-mediated cardiac fibrosis in pressure-overloaded myocardium. Circulation 136, 940-953. doi: 10.1161/circulationaha.117.027889

Verma, S. K., Garikipati, V. N. S., and Kishore, R. (2017b). Mitochondrial dysfunction and its impact on diabetic heart. Biochim. Biophys. Acta Mol. Basis Dis. 1863, 1098-1105. doi: 10.1016/j.bbadis.2016.08.021

Wahid, F., Shehzad, A., Khan, T., and Kim, Y. Y. (2010). MicroRNAs: synthesis, mechanism, function, and recent clinical trials. Biochim. Biophys. Acta Mol. Cell Res. 1803, 1231-1243. doi: 10.1016/j.bbamcr.2010.06.013 
Ward, Z. J., Bleich, S. N., Cradock, A. L., Barrett, J. L., Giles, C. M., Flax, C., et al. (2019). Projected US state-level prevalence of adult obesity and severe obesity. N. Engl. J. Med. 381, 2440-2450. doi: 10.1056/nejmsa1909301

Weinrauch, L. A., Burger, A., Gleason, R. E., Lee, A. T., and D'elia, J. A. (2005). Left ventricular mass reduction in type 1 diabetic patients with nephropathy. J. Clin. Hypertens. 7, 159-164. doi: 10.1111/j.1524-6175.2005.04307.x

Wiviott, S. D., Raz, I., Bonaca, M. P., Mosenzon, O., Kato, E. T., Cahn, A., et al. (2019). Dapagliflozin and cardiovascular outcomes in type 2 diabetes. N. Engl. J. Med. 380, 347-357.

World Health Organization (2018). Taking Action on Childhood Obesity. Geneva: World Health Organization.

Xu, D., Zhang, X., Chen, X., Yang, S., and Chen, H. (2020). Inhibition of miR223 attenuates the NLRP3 inflammasome activation, fibrosis, and apoptosis in diabetic cardiomyopathy. Life Sci. 256:117980.

Yajnik, C. S., Fall, C., Coyaji, K. J., Hirve, S., Rao, S., Barker, D., et al. (2003). Neonatal anthropometry: the thin-fat Indian baby. The Pune maternal nutrition study. Int. J. Obes. 27, 173-180.

Yang, F., Li, A., Qin, Y., Che, H., Wang, Y., Lv, J., et al. (2019). A novel circular RNA mediates pyroptosis of diabetic cardiomyopathy by functioning as a competing endogenous RNA. Mol. Ther. Nucleic Acids 17, 636-643.

Yang, F., Qin, Y., Wang, Y., Li, A., Lv, J., Sun, X., et al. (2018). LncRNA KCNQ1OT1 mediates pyroptosis in diabetic cardiomyopathy. Cell Physiol. Biochem. 50, 1230-1244.

Ye, Y., Bajaj, M., Yang, H.-C., Perez-Polo, J. R., and Birnbaum, Y. (2017). SGLT-2 inhibition with dapagliflozin reduces the activation of the Nlrp3/ASC inflammasome and attenuates the development of diabetic cardiomyopathy in mice with type 2 diabetes. Further augmentation of the effects with saxagliptin, a DPP4 inhibitor. Cardiovasc. Drugs Ther. 31, $119-132$.
Yi, F., Shang, Y., Li, B., Dai, S., Wu, W., Cheng, L., et al. (2017). MicroRNA-193$5 \mathrm{p}$ modulates angiogenesis through IGF2 in type 2 diabetic cardiomyopathy. Biochem. Biophys. Res. Commun. 491, 876-882.

Zarich, S. W., Arbuckle, B. E., Cohen, L. R., Roberts, M., and Nesto, R. W. (1988). Diastolic abnormalities in young asymptomatic diabetic patients assessed by pulsed Doppler echocardiography. J. Am. Coll. Cardiol. 12, 114-120.

Zhang, M., Gu, H., Xu, W., and Zhou, X. (2016). Down-regulation of IncRNA MALAT1 reduces cardiomyocyte apoptosis and improves left ventricular function in diabetic rats. Int. J. Cardiol. 203, 214-216.

Zhang, W., Xu, W., Feng, Y., and Zhou, X. (2019). Non-coding RNA involvement in the pathogenesis of diabetic cardiomyopathy. J. Cell Mol. Med. 23, 58595867.

Zheng, D., Zhang, Y., Hu, Y., Guan, J., Xu, L., Xiao, W., et al. (2019). Long noncoding RNA Crnde attenuates cardiac fibrosis via Smad3-Crnde negative feedback in diabetic cardiomyopathy. FEBS J. 286, 1645-1655.

Zinman, B., Wanner, C., Lachin, J. M., Fitchett, D., Bluhmki, E., Hantel, S., et al. (2015). Empagliflozin, cardiovascular outcomes, and mortality in type 2 diabetes. N. Engl. J. Med. 373, 2117-2128.

Conflict of Interest: The authors declare that the research was conducted in the absence of any commercial or financial relationships that could be construed as a potential conflict of interest.

Copyright (C) 2021 Rai, Lee, Gomez, Rajendran, Khan and Garikipati. This is an open-access article distributed under the terms of the Creative Commons Attribution License (CC BY). The use, distribution or reproduction in other forums is permitted, provided the original author(s) and the copyright owner(s) are credited and that the original publication in this journal is cited, in accordance with accepted academic practice. No use, distribution or reproduction is permitted which does not comply with these terms. 